\title{
Between Islamic Learning and Philological Nationalism: Mullah Mahmûdê Bayazîdî's Auto-ethnography of the Kurds
}

\author{
Michiel Leezenberg \\ University of Amsterdam, The Netherlands \\ m.m.leezenberg@uva.nl
}

\begin{abstract}
This article deals with the ethnographic and philological works of the nineteenth-century Kurdish scholar Mullah Mahmûdê Bayazîdî, which mark a crucial stage in the history of vernacular Kurdish-language learning. It turns out that Bayazîdî, although working in the service of the then Russian consul, Auguste Jaba, cannot be called either a "native informant" nor an "orientalist scholar". After providing some historical background, I discuss Bayazîdî's main writings and their significance. I then discuss his conceptions of language, literature, local tradition or culture, and history, concluding that none of these bears any traces of modern Western philology or romantic nationalism. Hence, his work cannot be qualified as "internalized orientalism", but, as it is written in a vernacular language, neither can it be wholly assimilated to classical Islamic learning.
\end{abstract}

\section{Keywords}

Islamic intellectual history - vernacular learning - Kurdish studies - Russian orientalism

For Jan Dost 


\section{Introduction}

Traditions of vernacular learning in the early modern Islamic world have hardly received the scholarly attention they deserve. ${ }^{1}$ When studied in detail, they turn out to undermine or complicate some widespread beliefs about the spread of nationalism to, and the hegemony of Western orientalism in, the modernizing Middle East. As an example of this, I propose to study the writings of Mullah Mahmûdê Bayazîdî, or Bazîdî (1797-1858 or 1868). These works not only have an inherent interest as probably the oldest local source on Kurdish customs and on the history of Kurdish learning and literature; they also mark a significant stage in the development of Kurdish vernacular learning. Next to a Kurdish translation of and a sequel to Sheref Khan Bidlîsî's sixteenthcentury Sherefname, a Persian-language chronicle of Kurdish principalities, Bayazîdî wrote works on Kurdish grammar, literature, and folklore, and also composed several collections of short prose texts. Despite the number and importance of these works, however, they have hardly, if at all, been discussed or even noticed - by later scholars in Kurdish studies, let alone elsewhere. Thus, despite his inherent interest, Bayazîdî is also absent in such influential works on the Kurds as Martin van Bruinessen's Agha, Shaykh, and State, David McDowall's Modern History of the Kurds, and Hakan Özoglu's Kurdish Notables and the Ottoman State. ${ }^{2}$ Moreover, Bayazîdî's contributions are rarely, if ever, done justice in historical accounts or the development of Kurdish studies. Even recent overviews, like the one by Sacha Alsancakli, reduce Bayazîlî's role to that of a "collaborator" or "informant". Such accounts risk reducing Kurdish (and other non-Western) scholars to mere "native informants" and reproducing the topos of modern orientalist knowledge as produced primarily, if not exclusively, by Western scholars. ${ }^{3}$

In fact, there is a long orientalist tradition in Western scholarship that sees the Kurds as primarily a rural and tribal people virtually without a high literate

1 I am indebted to the audiences at the international conference Kurdistan: Between Past and Future, Soran University, and at the conference New Perspectives on Writing the History of the Kurds, Oxford University, for their comments on earlier versions of this paper; special thanks to Jelle Verheij and Nelida Fuccaro for their help with archival materials, and to Maaf Barzani for his help in securing a copy of Dêreshî's Sherefname edition. Thanks are also due to Djene Bajalan, Jan Dost, Halkawt Hakim, Se'îd Dêreshî, and Serdar Uçar.

2 Martin van Bruinessen, Agha, Shaykh, and State: On the Social and Political Structures of Kurdistan (London: Zed Press 1991); David McDowall, A Modern History of the Kurds (London: I.B. Tauris, 1996); Hakan Özoglu, Kurdish Notables and the Ottoman State: Evolving Identities, Competing Loyalties, and Shifting Boundaries (Albany: State University of New York Press, 2004).

3 Sacha Alsancakli, "The Early History of Kurdish Studies (1787-19o1)", WI 55 (2016), 55-88, esp. $78-79,82$. 
culture of its own, and that hence pays rather less attention to local authors and cultural and intellectual developments than to ethnography and social and political history. The reception, or marginalization, of Bayazîlîs work marks an early stage in the creation of this ethnographic image and is indicative of the wider process by which European - in particular, imperial Russian - orientalism reduced literate local scholars to anonymous and primarily oral "native informants".

Likewise, Bayazîdî is relatively unknown in Kurdish circles of the nineteenth and early twentieth centuries. I have not come across any evidence that Bayazîdî's writings were known to local medrese pupils, either in his own age or in later years, and most of his writings were not published until over a century after they were written. In fact, there is no evidence that any of them reached a Kurdish audience independently from, or prior to being printed in, the Soviet Union from the 1960 os.

Thus, Bayazîdî's importance hardly resides in his being widely read by later generations of Kurdish religious scholars or nationalist activists. Here, however, I will not discuss the causes of this lack of impact in detail; my aim is primarily to discuss his work itself, as marking a significant moment in the development of Kurdish vernacular learning against the background of a modernizing and centralizing Ottoman state and of an encroaching Russian empire. I will discuss, first, exactly what conceptions of language, literature, religion, and tradition or culture can be found in Mulla Mahmûdê Bayazîdî's writings; second, to what extent these conceptions have been shaped by the categories of Western philological orientalism, especially as they inform the work of his close collaborator and patron Auguste Jaba; and third, whether such influence amounts to a kind of internalized orientalism or "self-orientalization". Finally, I will briefly discuss the fate of Bayazîlî's writings in later Russian orientalism. ${ }^{4}$

\section{Non-Western Nationalism: Internalized Orientalism?}

A detailed study of Bayazîdî's work raises questions of a more general nature. First and foremost, it explores the role of local traditions of philological learning in the development of national identities, a topic which has been studied rather more extensively in the case of Western and Central Europe. Second, it questions the virtual identification of orientalism with modern philology in

4 Meanwhile, a very welcome French translation of Bayazîlî's Adat û Rusûmâtname, prepared by Joyce Blau and Sandrine Alexie, was published as Us et coutumes des Kurdes (Paris: Geuthner, 2015). 
general, especially regarding its constitutive influence on non-Western European nationalisms, as has been claimed by Stathis Gourgouris concerning the neo-Hellenic movement, and by Marc Nichanian for modern Armenian nationalism. 5

The latter argument builds not only, and most obviously, on Edward Said's critique of orientalism but also on Michel Foucault's archaeological account of the origins of modern philology. Famously, in The Order of Things, Foucault argues that modern Western concepts of language as a historically developing organism, rather than a transparent medium of representation, and of literature as an autonomous and purely aesthetic form or realm of language, developed as part of the rise of the modern human sciences in the nineteenth century. By extension, one might argue that categories like religion, culture (or tradition), and history likewise have their origin in the modern philological human sciences. ${ }^{6}$ Such claims, however, leave unanswered the question of exactly how these modern categories became universalized, or spread from Western to non-Western settings. Bayazîdî's writings, as I hope to make clear below, form a particularly interesting testing ground for such hypotheses and questions.

Let us first address the more general problematic of non-Western nationalism in somewhat greater detail. There is a widespread belief that newly hegemonic nationalist ideas were based on German romantic-nationalist categories; by extension, they employed new notions of language and literature that had been developed by modern - primarily, German - philologists and, more specifically, orientalists. Further, and following Gourgouris, Nichanian virtually identifies "nationalist" philology with orientalism as defined by Edward Said: modern philological methods, he argues, simultaneously constitute a national

5 Joep Leerssen, National Thought in Europe: A Cultural History (Amsterdam: Amsterdam University Press, 2006); Stathis Gourgouris, Dream Nation: Enlightenment, Colonization, and the Institution of Modern Greece (Stanford CA: Stanford University Press, 1996); Marc Nichanian, Le deuil de la philologie (Entre l'art et le temoignage, vol. II) (Geneva: Metis Presses, 2007). Nichanian's argument is especially relevant in the present context: for a long time, Kurds and Armenians lived in a geographically overlapping area, and had a partly shared or converging historical experience.

6 For the modern reconceptualization of language and the emergence of a purely aesthetic concept of literature, see Michel Foucault, Les mots et les choses: Une archéologie des sciences humaines (Paris: Gallimard, 1966), 292-313; English translation The Order of Things (New York: Random House 1970), 280-302. For 'religion', see W.C. Smith, The Meaning and End of Religion (New York: Macmillan 1963), 15-5o; famously, this critique was subsequently extended by Talal Asad in "The construction of religion as an anthropological category", in Genealogies of Religion (Baltimore: Johns Hopkins University Press 1993), 27-54. For "tradition", see R. Bauman \& Ch. Briggs, Voices of Modernity (Cambridge: Cambridge University Press 2003), 165-89, $267-76$. 
self and a non-Western other. This process, however, becomes much more complicated in the case of non-Western European "philological nationalisms", like the neo-Hellenic and Armenian movements emerging out of the Ottoman and, in part, the Russian Empires. Nichanian argues that modern philology and what he calls its "twin sister", literature, imply a redefinition of the (national) self as "native" - that is, as endowed with a national language and literature that are oral as much as literate, and with a folkloric culture or tradition that is pagan as much as Christian. Thus, Nichanian claims that the introduction of nineteenth-century modern philological orientalism constituted the Armenians as local natives possessing a timeless pre-Christian tradition of pagan folklore; in this sense, he argues, Armenian philological nationalism amounts to a "self-orientalization" - that is, to the internalization of hegemonic categories of Western European (in particular, German) orientalism. The Armenian native, that is, is not simply an oriental other but is also, and simultaneously, a national self. ${ }^{7}$

The accuracy of these claims concerning the Armenians need not concern us here; rather, the question we will explore is whether a similar argument may be made concerning the new forms of Kurdish vernacular learning that emerged around the same time. In earlier studies of Kurdish intellectual history, I have argued, first, that in the eighteenth century, one may witness the first phase of the so-called vernacularization of Kurdish (i.e., the new literate and learned use of the Kurdish language) as part of a wider process of vernacularization in the Ottoman Empire; and second, that in late imperial Russian and early Soviet scholarship, one may observe a "folklorization" of the Kurds (i.e., a reconceptualization of the Kurds as a people endowed primarily with a national oral folkloric tradition rather than a written literature). ${ }^{8}$ It then becomes tempting to see Bayazîdî - who wrote his main texts arguably under some form of Russian imperial influence - as marking a crucial stage in this development. Extending this thesis, one could then argue that the vernacularization and folklorization of Kurdish culture is a process similar to the one described by Nichanian and Gourgouris. Thus, the questions to be explored are, first, whether Kurdish national consciousness emerged under the hegemonic

7 Nichanian, Mourning, 97-149; cf. Gourgouris, Dream Nation, esp. 122-54. For more on the role of folklore research in the emergence of neo-Hellenic nationalism, see also Michael Herzfeld, Ours Once More: Folklore, Ideology, and the Making of Modern Greece (Austin: University of Texas Press, 1982).

8 M. Leezenberg, "Eli Teremaxî and the vernacularization of Kurdish medrese learning". Iranian Studies 47:5 (2014), 713-33; id., "Soviet Kurdology and Kurdish Orientalism", in The Heritage of Soviet Oriental Studies, ed. by M. Kemper \& S. Conermann (London: Routledge 2011), 86-102; id., "The Vernacular Revolution: Reclaiming Early Modern Grammatical Traditions in the Ottoman Empire", History of the Humanities 1:2 (2016), 251-75. 
categories of philological orientalism, as has been claimed for Greek and Armenian nationalism; and, second, exactly what role Kurdish actors played in this process. In this context, I will explore whether and to what extent Bayazîdî's writings involve translations of Western philological and ethnographic categories of language, folklore, tradition, and nationhood. In doing so, I hope to bring some nuance to - sometimes sweeping - claims concerning Western "orientalist hegemony". In particular, I will trace the extent to which Bayazîdî's categories are distinct from those of modern philology, and the extent to which Bayazîlî's contribution to the development of Kurdish studies has been marginalized by reducing him to the status of a "native informant".

It has proved equally tempting to read older Kurdish texts in the light of a later nationalism that posits a distinctly Kurdish language and culture, but one should try to resist projecting back such later conceptions and identities onto an era in which the very categories of romantic nationalism were still in the process of being articulated, let alone universalized. More specifically, we should resist the temptation to systematize the scattered remarks of earlier authors into a unified and coherent "doctrine", and to depict them as "anticipating" some later doctrine (in this case, romantic nationalism). ${ }^{9}$ Rather, these romantic concepts and doctrines are themselves very much Western European creations of the nineteenth century; hence, one should not assume their universal applicability, but rather explore whether, how, and when they became universalized. For this reason, although I will trace Bayazîdî's views along the four axes of language, literature, religion, and tradition, I do not assume these concepts as in any sense given - that is, as either neutral analytical notions or as categories that unify an entire discursive field. ${ }^{10}$ Rather, my point is precisely to show how these central notions radically changed meaning and content in the course of the nineteenth century.

\section{Historical Background}

The early Tanzimat history of the Kurdish provinces along the Russo-Persian border is rather less well known that that of other Kurdish regions, like Botan, Rawanduz, and Diyarbakir, let alone other outer regions of the Ottoman

$9 \quad$ This is what Quentin Skinner calls "the mythology of doctrines", in "Meaning and Understanding in the History of Ideas", reprinted in idem, Visions of Politics, Vol. I: Concerning Method (Cambridge: Cambridge University Press, 2002), 57-89, esp. 6o-64.

10 For these broader theoretical claims, see Michel Foucault, The Archaeology of Knowledge (London: Routledge, 1989 [1972]), esp. 44-54; cf. John Bowen, Muslims through Discourse (Princeton: Princeton University Press, 1993), 10-11. 
Empire during this period, like the Danube principalities. At present, we know surprisingly little about the Kurdish principalities on the Ottoman Empire's eastern front line, even though it was a crucial front line in its recurrent conflict with the expanding Russian Empire." Yet, developments here, though perhaps not quite as dramatic as in the Balkans, were radical enough. This applies also to events in Bayazîlî's native region, which was centred around the town of Bayazîd, or present-day Dogubeyazit, on the Turkish-Iranian border. ${ }^{12}$ Since the seventeenth century, Bayazîd had been a sancak, or administrative unit, of the vilayet of Erzurum. It was governed by hereditary Kurdish rulers, who, among other achievements, in the eighteenth century had built the Ishakpasha Palace. ${ }^{13}$ Bayazîd lay at the frontier not only between the Ottoman and Qajar Empires, but also, and more importantly in the nineteenth century, between the Ottoman Empire and Russia, the rising imperialist power. The 182122 Ottoman-Persian War had seen some temporary Persian advances on Ottoman territory, but the subsequent 1823 Treaty of Erzurum essentially reaffirmed the 1639 boundary between the two empires. More momentously, during the 1828-29 war with Russia, the towns of Kars and Bayazîd, as well as their surroundings, were occupied by the Russian army. Although Russia subsequently withdrew from these regions, following the 1829 Treaty of Edirne, it henceforth claimed the right to protect the Ottoman Empire's Christian subjects in these eastern provinces, just as it had done for the Christians living in the empire's Western provinces in the 1774 Treaty of Küçük Kaynarca. In their imperialist rivalry, moreover, both the Russian and the British Empires established consulates in the nearby provincial capital, Erzurum.

Two foreign visitors to the region have become particularly famous. First, during the 1828-29 war, the Russian poet Alexander Pushkin joined the invading Russian troops, travelling alongside the army as far as Erzurum. Pushkin showed a special interest in the local Yezidis (at the time some three hundred families, who lived at the foot of Mount Ararat and recognized the sovereignty of the tsar), stating - with some apparent relief - that they were not devilworshippers as their detractors claimed:

11 For a recent collection of papers that calls attention to the Eastern Ottoman Empire, see Y.T. Cora, D. Derderian \& A. Sipahi, The Ottoman East in the Nineteenth Century: Societies, Identities and Politics (London: I.B. Tauris, 2016).

12 For basic information, see Şemseddin Sami, Kâmûs al-alâm II: 1234 (modern Turkish transcription in M.E. Bozarslan, Tarihteki ilk Türkçe ansiklopedide Kürdistan ve Kürdler (Istanbul: Deng Yayinlari, 2001), 63-64; Islam Ansiklopedisi II: 368-69.

13 Yüksel Bingöl, Der Ishak Pascha Palast in Doğubayazıt am Berg Ararat: ein Beitrag zur Baugeschichte eines türkischen Palastes im 18. Jahrhundert. (Berlin: Edition Orient, 1982). 
According to their law, cursing the devil was seen as unseemly and base, for he is now an unfortunate, but that in time, he can be forgiven, since no limits can be placed on the mercy of Allah... I was very glad for the Yazidis, that they did not worship Satan; and their errors already seemed to me much more pardonable. ${ }^{14}$

In these renderings of native remarks, one hears echoes of the Sufi belief that Iblîs, in refusing to obey God's order of worshipping Adam, is actually most faithful to the divine wish for humans not to worship anyone but God, for which he is punished until he will take his rightful place next to God at the end of time. Apart from such comments, however, Pushkin largely abstains from comments on the local Kurdish rulers or population.

Equally famously, Bayazîd also provides the setting for an episode involving the French orientalist and diplomat Pierre Amédée Jaubert. In 1805, Jaubert passed through Bayazîd on his way to the court of Fath Ali Shah in Qajar Iran, where he had been sent by Napoleon in order to negotiate a Russo-Persian alliance. The local ruler, Ibrahim Pasha, finding the foreign visitor suspect, had him imprisoned, but in 1806 , the prince succumbed to the plague. His successor, the rather more benign Mahmûd Pasha, had Jaubert released, apparently against the wishes of the Ottoman provincial authorities, who had meanwhile been notified of the matter. ${ }^{15}$ We will return to this episode below.

The Tanzimat reforms, preceded by the 1826 destruction of the Janissary corps and initiated by the Gülhane Rescript of 1839, brought major changes to the Bayazîd region, such as military conscription, administrative centralization, and, most dramatically, the end of hereditary local rule. Educational reforms were rather slower in reaching the provinces on the Russian frontier, and major changes in the land regime only materialized after the Land Law of 1858 . Despite such differences in timescale, the reforms had dramatic repercussions for the Kurdish region as a whole. The Ottoman defeat at the Battle of Nizip in 1839 had led Bedir Khan Beg, the hereditary Kurdish ruler (mîr) of Botan, to join forces with his erstwhile rivals, Nûrullâh Beg of Hakkârî and Khan Mahmûd of Muks, in defiance of the central government. It would take the Ottoman army the better part of the next decade to defeat this triumvirate; eventually,

14 Alexander Pushkin, Puteshestvie v Arzrum (1836); English translation, "A Journey to Arzrum", in Mikhail Lermontov, A Hero of Our Time (Oxford: Oxford University Press, 2013), 141-84, esp. 169.

15 Pierre-Amédée Jaubert, Voyage en Arménie et en Perse fait dans les années 1805 et 1806 (Paris: Pélicier, 1821), esp. 30-89. 
all three men were captured and sent into exile. ${ }^{16}$ Rather less is known about Ibrahim Pasha's grandson, Behlûl Pasha, the last hereditary ruler of Bayazîd, who had ruled over the sancak since 1816; apparently, he was ousted by the Ottomans at some point in the 1840 , and died in 1854 . Nikitine reports that during the 1828-29 Russo-Ottoman War, Behlûl Pasha sought in vain to ally himself with the Russians, ${ }^{17}$ but Kurdish historian Mehmet Gültekin states that Behlûl surrendered the city to the Russian army and was sent to Tiflis as a prisoner of war. ${ }^{18}$ Captain James Brant, the British consul at Erzurum, presents yet another view of the pasha: in a report to the British ambassador in Istanbul dated 24 April 1846, he bemoans not only the "shameful state" of Bayazîd province, which is "given to the most barefaced rapine of all the rogues of the province", but also the unwillingness or inability of the local authorities to do anything about it. The region is described as having been made unsafe by the pervasive banditry of Kurdish tribes (some of them Sunni Muslims, others consisting of Yezidis), and as knowing no taxation apart from the extortionate practices carried out by local chieftains. Behlûl Pasha, he writes, "Comes into his selamlik for about a quarter of an hour every morning, and after smoking a pipe and drinking a coffee, he retires into his harem, and can no more be seen."19 Brant makes no mention of any active or passive support for the Russians on the pasha's side. Regardless of the accuracy or reliability of his report, the available evidence does indeed suggest that Behlûl was not as ambitious and energetic (let alone violent) a ruler as Bedir Khan Beg or Nûrullâh, but this was actually good news for the central Ottoman authorities - his fiefdom appears to have been dismantled without any great upheaval.

The Crimean War (1853-56) marked a new stage in the confrontation between the Ottoman and the Russian Empires. At first, Ottoman troops advanced into the Southern Caucasus, but by the summer of 1855 , the Russians started an offensive towards Kars, which eventually fell in November of that year. At the 1856 Treaty of Paris, Russia pledged once again to give up the areas

16 Cf. Suavi Aydın \& Jelle Verheij, "Confusion in the cauldron: Some notes on ethno-religious groups, local powers and the Ottoman state in Diyarbekir province, 1800-1870", in Social Relations in Ottoman Diyarbakir, 1870-1915, ed. by J. Jongerden \& J. Verheij (Leiden: Brill, 2012), 15-54, esp. 36-38. On Khan Mahmûd, see also Sinan Hakan, Müküs Kürt mirleri tarihi ve Han Mahmud (Istanbul: Pêrî Yayınları, 2002).

$17 \quad$ Nikitine, Kurdes, 192.

18 See $<$ http://www.ehmedexani.org/index.php?page=tarih\&op=openPage\&id=31\&title=M ELA-MEHMUD-BAYAZID\%CE $>$ (accessed April 9, 2013).

19 FO 195-227, nr. 26 1846.04.24; cf. Consul Brant, "Notes of a Journey through Part of Kurdistán, in the Summer of 1838", Journal of the Royal Geographic Society 10 (1840), 341-432, esp. 418-28. 
it had conquered in Eastern Anatolia. ${ }^{20}$ By that time, however, all Kurdish principalities in the region had been dismantled.

We know the political history of Bayazîd only in its barest outline; we know even less about the social and economic history of the region. Thus, there are no detailed studies of relations between local Kurds and Armenians; between tribes and the non-tribal population; or between Muslim Kurds and Yezidis. Travellers report that there were distinct Armenian and Kurdish quarters in the town itself. Apparently, the construction of the Ishakpasha Palace had placed a heavy financial burden on the local peasant population, making the rulers rather unpopular; several authors even mention uprisings against the local mîrs. ${ }^{21}$ According to Oleg Vil'cevskij, there was an uprising in the pashaliks of Bayazîd and Van around 1815, which was joined by nomadic Kurds from the Khoy, Erivan, and Nakhichevan districts; eventually, however, this uprising was suppressed by the serasker of Erzurum. ${ }^{22}$ Vil'cevskij describes these uprisings as more than just intrigues by local chieftains or brigandage by local tribes, seeing them as led by the obabashi [sic], which he qualifies as an "embryonic local bourgeoisie". Clearly, his analysis is shaped by Marxist doctrines concerning feudal and proto-capitalist modes of production and the development of class consciousness among Kurdish workers and peasants, but it assumes that, rather than exploring whether and to what extent, the region underwent any capitalist penetration in the first half of the nineteenth century.

Not much is known, either, on the political preferences and loyalties of the Kurdish population of the region, except that some Kurdish tribes sided with the Russians or were increasingly suspected by the Ottomans, either of having done so or of being prone to do so. ${ }^{23}$ Local Kurdish mîrs and tribal leaders

$20 \quad$ For more Russian and English sources on the military aspects of these wars, see Aleksandr Kleonokovic Ushakov, Geschichte der Feldzüge des General Paskewitch in der asiatischen Türkei (Leipzig: Kollmann, 1838); George Kmety, A Narrative of the Defence of Kars on the 29. of Sept. 1855, Translated from the German of George K. (London: Ridgway, 1856); H.A. Lake, Kars and our Captivity in Russia (London: Bentley, 1856); Narrative of the Defence of Kars (London: Bentley, 1857); V. Monteith, Kars and Erzeroum. (London: Longman, Brown, 1856); Dr Sandwith, Narrative of the Siege of Kars (London: Murray, 1856); Allen, W.E. \& Muratoff, Paul, Caucasian Battlefields: A History of the Wars on the TurcoCaucasian Border, 1828-1921 (Cambridge: Cambridge University Press, 1953). Jaubert, Voyage, 69, states that the local population hated the palace because it had been financed by extortion and robbery.

Ekonomika kurdskoi kcevoi sel'skoixoziaistvennoi oshciny Zakavkaz'ia prilegaiuschcix raionov vo vtoroi polovine XIX v. (Economy of the Kurdish agrarian nomadic community in the Transcaucasus and adjacent districts in the second half of the 19th century). Sovietskaja Etnografija, no. 4-5 (1936); quoted in B. Nikitine, Les kurdes (Paris: Imprimerie nationale, 1956), 192-93. 
maintained an ambivalent position between the rival empires, as they were in a position to switch loyalties or even to vote with their feet. Thus, Henry Trotter describes how, as late as 1880, Kurdish nomadic tribes in the Ottoman, Russian, and Persian Empires would escape both taxation and conscription, not to mention criminal prosecution, by migrating across the border whenever the need arose. ${ }^{24}$

It is against this background of competing empires and rising imperialism, and of accelerating Ottoman centralization and declining Kurdish emirates, that we should locate Bayazîdî's life. Our oldest - indeed, virtually the only - source of biographical information is a letter by Auguste Jaba, dated 10/22 September 1857, reproduced in Lerch's introduction to Jaba's Recueil. Although it is not free from errors, this source provides us with basic information about Bayazîdî himself and hints at his involvement in some of the major political developments of his day. ${ }^{25}$ The letter states that Bayazîdî was educated first in his native Bayazîd, and subsequently in Tabrîz, across the Ottoman-Qajar frontier; apparently, he was fluent not only in his native Kurdish but also in Arabic, Persian, and Turkish.

About Bayazîdî's education in either his native town or Tabrîz, we have only circumstantial evidence. In his brief but important sketch of Kurdish medrese life (reproduced in Jaba's 186o collection), he lists the most important texts studied in the first years of medrese education in rural Northern Kurdistan. It

Tipografiya Shtaba, 1900). Apparently, this work was quickly translated into Ottoman Turkish; next, this translation was rendered into modern Turkish by Muhammed (Hoko) Varli (Xani) and published by Sipan Yayincilik in 1995. A new Turkish translation appeared more recently as Ibrahim Kale (çev.) Osmanli Iran Rus savasinda Kürtler (19.yüzyil) (Istanbul: Avesta, 2010).

24 Henry Trotter, “Report on the Kurds", No. 134 of Parliamentary Papers (Turkey no.6, 1881).

25 Jaba, Recueil, viII-X. These comments contain minor errors: thus, Jaba writes Pehloul rather than Behloul, and mistakenly identifies Khan Mahmûd as Bedir Khan Beg's brother. Musaelyan, "First", 4 notes that in 188o, Jaba stated his intention of writing Bayazîlî's biography, but apparently, he never actually did so. Some brief further comments on Bayazîdî appear scattered in P. Lerch, Forschungen über die Kurden und die iranischen Nordchaldäer (St. Petersburg: Imperial Academy of Sciences, 1857-1858). See also Ferhad Pirbal, Mela Mahmudî Bayazîdî, 1797-1867: Yekemîn çîroknûsî kurd (Arbil: Aras, 200o). Sagniç's brief biographical sketch in his Dîroka Wêjeya Kurdî (Istanbul: Weşanên Enstîtuya Kurdî ya Stenbolê, 2002, 443-45) appears to be entirely derived from these sources, to which it adds a few minor errors, e.g., mistakenly writing Adab rather than 'Adet in the title of Bayazîdî's ethnographic collection. 
seems reasonable to infer that he himself, too, had followed this curriculum, but, as he does not say so explicitly, this is no more than a plausible conjecture. The most remarkable items on this list are a number of elementary Kurdishlanguage textbooks on the Arabic lexicon (Ehmedê Khanî's Nûbihara piçûkan), on the principles of faith (Eqîdeya êmanê, by the same author), and on grammar (Tesrîf, Zurûf, and Terkîb, all of which he attributes to Mullah Yûnus Khalqatînî, d. 1791). The list also mentions a number of Arabic-language authors, like Sa'ad al-Dîn al-Taftazânî and Yûsuf al-Ardabîlîi; these are all affiliated with the Shafi'ite madhhab. This enumeration is remarkably consistent with the lists of obligatory textbooks provided by other, more recent medrese graduates from Northern Kurdistan, suggesting that a more or less stable and specifically Kurmanjî and Shafiî curriculum had crystallized by around 1800 at the latest and survived intact well into the twentieth century. ${ }^{26}$

According to Jaba, Bayazîdî was highly respected among the local ulama already at an early age. This claim makes it tempting to identify Bayazîdî with a local Kurdish scholar named "haji Mahmûd" whom the Polish-born Protestant missionary Felician von Zaremba repeatedly met during his 1830 sojourn in Bayazid and who, in his words, "is seen as the most learned mullah here". ${ }^{27}$ Unfortunately, however, von Zaremba provides no further details either of these visits or of the mullah involved. Mehmet Gültekin is convinced that the local scholar is indeed Mahmûdê Bayazîdî. This may well be, but Bayazîdî was only some 33 years old at the time, and we have no independent evidence that he had already completed the pilgrimage to Mecca at that age, so this identification is as tentative as it is tempting. ${ }^{28}$

From the scanty sources, it is unclear whether Bayazîdî actually worked at Behlûl's court or was in Behlûl's service, but he does seem to have received some sort of support or patronage from the pasha. It is also unclear exactly when this patronage of the last semi-independent Kurdish ruler of Bayazîd came to an end. At some point before 1854 , and more probably in the late 1840 , Bayazîdî left his native town for Erzurum. In 1846, Hafiz Pasha, the "military mushir", charged him with an important mission to Bedir Khan Beg, who had revolted against the Ottoman government in 1846 and would eventually be captured and exiled in 1847. A year later, the then governor of Erzurum, Kâmil Pasha, charged Bayazîlî with a similar mission to Nûrullâh Beg, the Kurdish

26 On the Northern Kurdish medrese curriculum, cf. Leezenberg, "Teremaxî", 727-32.

27 "Nochmals besuchte ich den Hadgi Mahmud, einen kurdischen Mullah, der hier für den gelehrtesten gilt". In "Reise des Missionars Zaremba in die Russisch-türkische Provinzen am Euphrat, vom April bis Juli 1830", Magazin für die neueste Geschichte der evangelischen Missions- und Bibelgesellschaften 16 (1831), 432-6o, esp. 456-57. 
chieftain of Hakkârî. Apparently, the Ottoman authorities were so pleased with Bayazîdî's handling of these sensitive diplomatic missions that he was made dragoman of Khan Mahmûd, the former mîr of Muks and the third member of the Kurdish triumvirate in revolt, who spoke nothing but Kurdish, and who had been exiled to Erzurum vilayet and placed under house arrest in the village of Khevash (present-day Gevaş, on the south-eastern shore of Lake Van). From there, however, Khan Mahmûd soon revolted, as a result of which Bayazîdî was imprisoned for two weeks. ${ }^{29}$

Another source, an anonymous article in issue 13 (1898) of Kurdistan, the first Kurdish journal, provides some further information about the diplomatic efforts of one "Mela Efendi", whom Musaelian has plausibly identified as Bayazîdî. ${ }^{30}$ It suggests that he had an ambivalent intermediary position between the Ottoman court and the local Kurdish rulers, and that he may even have been involved in some form of double dealing. Sent to Bedir Khan's court in Botan, he reportedly asked the local Ottoman commander-in-chief, Othman Pasha, not to attack before his return; Othman, however, had objected to Mahmûd's diplomatic efforts from the start, and attacked without waiting for Bedir Khan's reply. The stiff resistance he subsequently encountered from the Kurdish rebels led him to infer that Bayazîdî had betrayed the secret plan for attack; hence, he had the latter arrested and sent to Istanbul to be tried. Bayazîdî was subsequently sent into exile in Van. Here, he became involved in Khan Mahmûd's revolt, but, according to this report, it was the latter rather than Mulla Mahmûd who was subsequently imprisoned for two weeks. Although Bayazîdî was able to avert a more severe punishment for Khan Mahmûd, he lost whatever trust the Ottoman authorities had had in his loyalty. ${ }^{31}$

The renewed military confrontation between the Ottoman and Russian Empires that broke out in 1853 also brought personal tragedy to Bayazîdî: his brother was killed in the war, and his son, who had remained in Bayazîd to continue his trade activities, lost all of his possessions. As a result, Bayazîdî was left in Erzurum without any source of income, and, as Jaba writes, "contemplated returning to Kurdistan". But at this time, in 1856 (presumably, following the Treaty of Paris that ended the Crimean War), Auguste Jaba returned to Erzurum as the Russian consul. Soon after, Bayazîdî became the latter's instructor in Kurdish, and subsequently the two started a fruitful collaboration in the collecting and writing of Kurdish-language materials. According to some

29 Jaba, Recueil, IX.

30 J.S. Musaelian, "On the first Kurdish edition of the Sharaf-nâma by Mullâ (Melâ) Mahmûd Bâyazîlî". Manuscripta Orientalia 5:4 (1999), 3-6, esp. 4.

$31 \quad$ Reprinted in Kurdistan: Yekemîn rozhnamey kurdî, ed. by K. Fuad (Baghdad: n.p., 1972), 43-44; Latin transcription in Kurdistan, ed. by M.E. Bozarslan (Stockholm: Weşanxana Deng, 1991), cild 1, 264-67. 
sources, Bayazîdî died in 1858; others, like Pirbal, give 1868 as the year of his death. ${ }^{32}$

From the above, it emerges that Bayazîdî played an important diplomatic role in some of the most dramatic social and political developments of his time - he appears to have been deeply involved in the Ottoman attempts to neutralize three of the most powerful Kurdish chieftains of the mid-nineteenth century. On his actual diplomatic activities, and on the precise character of his relations both with Kurdish rulers and Ottoman authorities, we do not know much at present, but Ottoman and other archives may yet yield further information on these questions. Likewise, although I have not yet come across any evidence that Mahmûd also had contacts with the British consul in Erzurum, it is quite possible that British archival sources, especially those dealing with the Erzurum consulate, contain relevant documents.

Here, however, it is less Bayazîlî's involvement in contemporary politics that primarily interests us than the contents and contexts of his writings. Of these, a good many have been preserved in European libraries, but relatively few have been published. Bayazîdî was one of the most important suppliers, if not the single most important supplier, of Kurdish manuscript materials for the libraries of imperial Russia; thus, of the 84 items listed in Rudenko's 1961 catalogue of Kurdish manuscripts in Leningrad (the vast majority of which had belonged to Jaba's Kurdish collection), no less than thirteen appear to have been written or copied by Bayazîdî. ${ }^{33}$ They range from elementary works aimed at language acquisition - like a Kurdish alphabet (no. 81, cat. no. GPB, Kurd 6), a model of verbal conjugation "according to the method of sarf and $n a h w^{\prime}$ (no. 78, cat. no. GPB Kurd 46), and a text of conversations (no. 76, cat. no. GPB Kurd 50) - to Kurdish translations of Bidlîsî's Persian-language Sherefname (no. 84, cat. no. GPB, Kurd 37) and a Turkish-language version of the story of Layla and Majnûn (no. 49, cat. no. GPB, Kurd 31), and several collections of tales (hikâya), as well as a description of Kurdish customs, the Adat $\hat{u}$ Rusûmâtnameyê ekradiyye (no. 82, cat. no. GPB, Kurd 34). Only some of these works have appeared in print; even fewer have been published in scholarly editions. All of these texts were written in Kurmanjî or northern Kurdish, but Bayazîdî is known to have written a number of works in Persian and Turkish as

32 This is not the place to discuss Jaba's life and career in detail, but see Marie de Testa \& Antoine Gautier, "Auguste de Jaba (1801-1894), diplomate orientaliste russe et la connaissance de la langue kurde", Le bulletin INALCO 1996, 79-90; expanded version in Drogmans et diplomates européens auprès de la Porte ottomane, ed. by De Testa \& Gautier (Istanbul: ISIS, 2003) 441-61. In 2013, Jaba's archive was acquired by, and transferred to, the University of Mardin.

33 M. Rudenko, Opisanie kurdskykh rukopisei leningradskikh sobranii (Moscow: Izdatel'stvo vostochnoi literatury, 1961). 
well. In fact, at the time, he was said to be the only Erzurum-based scholar whom the Ottoman rulers entrusted with the translation of Turkish texts into Persian. ${ }^{34}$

The published writings by Bayazîdî, which will be the focus of the discussion below, are the following:

- Adat û Rusûmâtnameyê Ekradiyye (henceforth $A R E$ ), first published over a century after it was written, in an edition by Margaret Rudenko containing the Arabic-script Kurmanjî text with a Russian translation. In 1979, Delîlo Îzolî privately printed a Latinized transcription of Rudenko's text edition, but this transcription does not feature a commentary or modern Kurdish translation, and it is unlikely to have had a very wide circulation. A Sorani translation appeared in 1982, and a Turkish translation in 1999. In 2006, Rashîd Findî published a Badînî (Kurmanjî) transcription in Arabic/Persian script, together with an Arabic translation, but it was not until 2010 that the Kurmanjî original was made available in the Latin alphabet, the only one available to the majority of Kurmanjî speakers in Turkey: in that year, two separate editions by, respectively, Jan Dost and Ziya Avci, appeared. ${ }^{35}$

- Camieya Rîsaleyan û Hikayetan (henceforth $C R H$ ), the selection of texts published with a French translation by Auguste Jaba in 186o; it includes forty "tales" (hikâya), as well as three short texts describing, respectively, the Kurdish tribes of Northern Kurdistan, in particular the area around Bayazid; a brief discussion of eight classical Kurdish poets; and an introductory text (muqeddime) on the science of sarf (morphology) and on the textbooks of linguistic learning used in Kurdish medreses. The Kurdish text of this collection, like that of $A R E$, was published in Latin transcription only in 2010; this transcription is based on the Arabic-script Kurdish text included in Jaba (186o) and, in fact, includes a photographic reproduction of that entire work. $^{36}$

34 Jaba, Recueil, $\mathrm{x}$.

35 Bayazidi, Mela Mahmud, 'Adat u rasumatname-ye Akradiye ("Habits and customs of the Kurds"), original manuscript (Kurmanjî in Ottoman characters) published by M.B. Rudenko, with an introduction and Russian translation: Nravy i Obycaj Kurdov (Moscow: Moskva Izd-vo vostočnoj literatury, 1963). M. Mahmut [sic] Beyazîdî, Adetên Kurdistan, ed. by D. Îzolî (The Hague: n.p., n.d. [1979]; Shukriye Resûl (tr.), Dabûnerîtî Kurdekan (Baghdad: al-Maktaba al-Wațaniyya, 1982); Kürtlerin örf ve adetleri, ed. by A. Önal (Istanbul: Peri, 1999); Pertûka 'adat û rusûmatname ekradiye ya Mela Mahehmûdê Bayezîlî (1799-1867), ed. by Rashîd Findî (Baghdad: al-Maktaba al-Wațaniyya, 20o6); Adat û Rusûmatnameê Ekradiye, ed. by Jan Dost (Istanbul: Nûbihar, 2010); Adat û Rusûmatnameyê Ekradiye, ed. by Ziya Avci (Diyarbakir: LIS, 2010). French translation by Joyce Blau and Sandrine Alexie, Us et coutumes des kurdes, (Paris: Geuthner, 2015).

36 Auguste Jaba, Recueil de notices et récits kourdes servant à la connaissance de la langue de la littérature et des tribus du Kurdistan (St. Petersburg: Imperial Academy of Sciences, 
- The Tawârîkhê Qedîmê Kurdistan or Ancient Chronicles of Kurdistan (henceforth $T Q K)$, Bayazîdî's Kurmanjî translation of Sheref Khan Bidlîsîs Persianlanguage Kurdish chronicle, the Sherefname. A photographic reprint of the manuscript was published in Moscow in 1986; a modern Kurdish transcription in Arabic script edited by Se'îd Dêreshî appeared in Duhok in 2007. ${ }^{37}$

- The Kitêba Tawârîkhê Cedîdê Kurdistan ("Modern Chronicles of Kurdistan", henceforth $т C K$ ): this work is allegedly lost, but a 50-page French translation of the introduction has been preserved. Elena Vasilyeva has published a Russian translation of this text, a Kurdish translation of which was subsequently included in Arabic-lettered rendering in Dêreshî's edition of Bayazîdîs translation of the Sherefname, and reproduced in a Latin-alphabet transcription in both Dost's and Avci's edition of $A R E . .^{38}$ Moreover, according to Nikitine, the famous Russian orientalist Vladimir Minorsky had recovered a number of unpublished works by Jaba (sic) that had been presumed lost, and in 1913 was given all remaining documents and linguistic notes by the latter's grandchildren, but he apparently never managed to publish any of this material. ${ }^{39}$ If this story is correct, perhaps not all hope is lost that Bayazîlî's modern chronicle may one day be found after all.

- A prose summary of EhmedêKhanî's mathnawîpoem MemûZîn (henceforth $M Z$ ). A Kurmanjî version, including the French translation by Alexandre Jaba, and with an introduction by Halkawt Hakim, was published in 1989; a reprint, transcribed by Xelîl Duhokî, appeared in $2008 .^{40}$

At first blush, few, if any, of these works unambiguously belong to the genres or disciplines of classical Islamic letters and learning, or adab; instead, they look

186o); Mela Mahmude Bazîdî, Cami'eya Risaleyan û Hikayetan bi Zimanê Kurmancî, ed. by Ziya Avci (Diyarbakir: LIS, 2010).

Mela Mahmud Bayazidi, Tavarih-i kadim-i Kurdistan; perevod Saraf-hana Bidlisi s persidskogo jâzyka na kurdski jâzyk; izdanie teksta, predislovie, ukazateli i oglavlenie K.K. Kurdoeva i Z.S. Musaélân Megjelenés (Moskva: Akademija Nauk, 1986). Şerefnameya Şerefxanê Bidlîsî Tercema Mela Mehmûdê Bazîlî̀, ed. by Se'îd Dêreşî (Duhok: Spîrêz, 2007). For a preliminary study, see Musaelian, "First".

38 E.I. Vasilyeva, "Kniga po istorii Kurdistana kotoraia ostanetsia nenaidennoi", Pamiatniki pis'mennosti i problemy istorii ii kultury narodov vostoka XxIv (1991), pt 3: 33-59. Dêreshî (ed.), Serefname, 55-84; Dost, Adat, 213-43; Avci, Adat, 25-42. As Bayazîdî's introduction is only preserved in a French translation, and in a retranslation of the latter text into present-day Kurdish, one should beware of inferring too much from its wording: it contains notably fewer Arabic loans and more Kurdish neologisms than other known texts by Bayazîdî. Thus, for "foundations", Dost's Kurdish text here has the neologism bingehan, whereas the original probably featured an Arabic loan, like eslan or usûl. Unfortunately, I had no access to the French 'original'.

39 Nikitine, Kurdes, 294-295.

40 Halkawt Hakim, "Mem u Zin: un résumé de Mahmud Bayazidi", Debireh, no 5, Paris, 1989, 181-92. Mem û Zîn, ed. by X. Duhoki (Diyarbakir: LIS, 2007). 
more like modern ethnographic and philological exercises specifically written for, and commissioned by, Western readers. This may tempt us to infer that the categories they employ have been supplied or shaped by those of modern Western philology and orientalist ethnography. It may seem difficult to believe that Bayazîdî, who by then already had a solid reputation among the local ulama, would have written all these works for Jaba alone; but, as noted above, he was unemployed and destitute at the time of his encounter with Jaba, so is likely to have been paid for his services. Apparently, these services included not only private instruction in Kurdish but also help on a Kurdish-French dictionary and the writing of commissioned texts on various topics. Vasilyeva discusses the question of whether Bayazîdî received any financial or other remuneration for these services, but she concludes we have no concrete information on these matters. ${ }^{41}$ The material preconditions for some kind of patronage on Jaba's part, however, are rather straightforward: after the dissolution of the Kurdish principalities, Bayazîdî no longer enjoyed the patronage of local rulers like Behlûl Pasha; his brother had lost his life and his son had lost his fortune in the war, so he could not turn to his own family for support either; and, as he himself observes, the local population neither showed the respect nor provided the material support for learning and scholars it had done in earlier times. ${ }^{42}$ Thus, apparently, he was without any major source of income when he met Jaba in 1856 .

The publishing history of these works is revealing in itself: they were first sent to the Imperial Academy in St. Petersburg in Russia, and in part made available in a bilingual edition published in 1860, which consisted of Arabicscript Kurdish texts plus French translations by Jaba. Significantly, this collection of Bayazîdî's writings was published as Jaba's work. It was not until the mid-twentieth century that Bayazîlî's works started appearing in Russian under his own name. It was even later, during the 1980s and 1990s, that the first Kurdish versions of Bayazîlîs writings were published either in Turkey or Iraq; most of these, in fact, were based on published Soviet editions rather than on the original manuscripts.

Most of Bayazîdî's texts on the Kurdish language appear to have remained unpublished; the most important of these seem to be the Tuhfet al-khillan $f \hat{\imath}$ zimanê kurdan or "Gift of friends in the language of the Kurds",43 and a 476 page manuscript entitled "Kurdish dialogues", in particular a section "On the knowledge of languages", which, according to Musaelian, also contains

\footnotetext{
41 Quoted in Dost, Adat, 214.

42 Jaba, Recueil, 14.

43 Cf. Rudenko, Opisanie, 105-107.
} 
autobiographical information. ${ }^{44}$ Bayazîdî's copy of Teremaxîs pioneering Tesrif was not published until 1971, and not in Moscow or Leningrad but in Baghdad. ${ }^{45}$ This remarkable neglect of Bayazîdî's philological work in imperial Russian and Soviet Kurdology appears to reflect the belief, quite widespread at the time, that Western scholars, although obviously dependent on locally educated informants, should not overly rely on the grammatical or linguistic information provided by the latter. I will return to this point below.

In all, Bayazîdî's life, career, and writings appear to have been crucially shaped by the dramatic political developments of his age - on the one hand, the centralizing Tanzimat reforms, which in the Kurdish provinces led to the pacification or abolition of the hereditary principalities and the introduction of military conscription; and on the other, the expansion of Russian imperial influence, whether in the guise of diplomatic representation like the consulate at Erzurum or in the shape of military occupation, as at Bayazîd during 1828 and 1829. Politically, Bayazîdî was heavily involved in these events - witness his missions for the Ottomans to the rebellious Kurdish chieftains and his extensive contacts with the consul of an enemy state. Below, we will discuss how his writings reflect these dramatic developments. His works, it will emerge, are neither simply part of traditional Islamic learning nor a mere carbon copy of modern Western forms of knowledge; rather, they mark a distinct moment in both descriptive content and theoretical vocabulary.

\section{Language}

To determine the character of Bayazîdî's writings, let us now have a closer look at Bayazîlî's concepts of language, literature, religion, and culture or tradition. The first question to be discussed is whether Bayazîlî has any sense of Kurdish as a distinct language, and of the Kurds as a distinct people defined by their language. More concretely, we should ask in exactly which sense, or senses, Bayazîdî uses expressions like Kurd, Ekrad, Kurmânc, and others. We cannot assume a priori that he uses these terms interchangeably; nor can we assume that he uses them in the present-day sense of an ethnic group or nation defined in terms of its language. To begin with, Bayazîdî rarely, if ever, uses the noun Kurd or the adjective kurdî, rather more often employing either the Arabic plural ekrâd or the Kurdish term kurmânc. ${ }^{46}$ Next, he consistently refers to

\footnotetext{
44 Musaelian, "First", 4.

45 For a more detailed discussion of Teremaxî's Tesrîf, cf. Leezenberg, "Teremaxî", 715-20.

46 The fact that Bayazîdî, like Khanî and other early Northern Kurdish authors, uses the term Kurmanj rather more often than Kurd somewhat limits the usefulness of Özoglu's Nota-
} 
the vernacular spoken by the Kurds as "the Kurmanjî language" (lîsanê kurmâncî), or more briefly as "Kurmanjî"; only once in $A R E$ does he use lîsanê kurdî. He seeks the etymological origin of the name Kurd or ekrâd in the Persian word gird "collection', that is, 'to collect or to gather"' (gird, yanî berhev $\hat{u}$ cemi ${ }^{c}$ kirin) $\cdot{ }^{47}$ As a people, however, he sees the Kurds as having not a Persian but an Arab origin, and as being "a part of those Arab peoples from whom they have become distinct" (ji wan tayifêd ereban miqdarek cuda bûyine). ${ }^{48}$ In $M Z$, he even speaks of "the Kurmanc community of the Arabs" (ta'îfa kurmancêd 'ereban) - that is, "Arab Kurds". ${ }^{49}$ He sees no contradiction or confusion here, but reproduces the long-standing practice of members of the Kurdish elites to claim a noble Arab descent, as in the case of the Kurdish rulers of the Botan emirate, who traced their genealogy to the Prophet's companion Khalid ibn Walîd. Likewise, in Ehmedê Khanî's romance Mem û Zîn, the fictitious prince Zeyneddîn is said to be of Arab origins, without this fact appearing to make him any less Kurdish:

Nesla wî ‘Ereb emîrê ekrad.../ Mensûb û muselselê Khalid.

A prince of Kurds, whose pedigree was Arab.../ Related to and descended from Khalid. ${ }^{50}$

Unlike these earlier sources, however, Bayazîdî claims Arab descent not only for the Kurdish rulers but also for the Kurds as a people. At first, he claims, they belonged to the Arab tayiffa and generally spoke Arabic, but at some point they became a separate tribe (qabîle) and developed - or rather, started speaking a separate language. Bayazîdî has no detailed account of how, if at all, this Kurdish language grew out of Arabic, other than through the "mixture" of Arabic and Persian elements: he claims that Kurdish is a "mixed" or "combined" language - "that is, it is blended, that is, put together from Persian and Iranian [or: by Persians and Iranians]" (zimanê berhev, yanîmexlutiye, yanî girdkiride ye ji Faris $\hat{u}$ Iraniyan), ${ }^{51}$ reflecting the belief, widespread among premodern Christian and Islamic authors, that languages are originally pure and only change as a result of corruption by its speakers, or through contact with other peoples, which results in "mixed" or "impure" languages. ${ }^{52}$

\footnotetext{
bles, ch. 2, search for the historical vagaries of the ethnic label Kurd.

47 Dost, Adat, 36.

48 Ibid, 33-36.

49 Duhoki, Mem, 23.

50 Xanî, Mem, bayt 365-68.

$5^{1} \quad$ Dost, Adat, 38.

$5^{2}$ Cf. Foucault, Mots, 50-51.
} 
More details of Bayazîdî's views on the Kurdish language emerge from his discussion of the different Kurdish dialects in the introduction to $T C K .{ }^{53}$ Here, he distinguishes four main dialects or dialect groups of Kurdish: the Rawendî dialect (spoken in the northern regions of Çaldiran, Kars, Bayazîd, Mush, Bitlis, and Van; this variety, he claims, is also the "language of the Kurdish re'âyas" in Harput - Elazig - and Diyarbakir ${ }^{54}$ ); the Hakkârî dialect (which, he claims, differs but little from the Rawendî dialect and is spoken in the provinces of Botan, Muks, and Hakkârî, in Ushnuwiyeh in present-day Iran, and further south, in what is presently called the Bahdinan region; it is in this dialect, he writes, that all Kurdish books and all Kurdish poetry have been written ${ }^{55}$ ); the dialect of Sulaymaniya (spoken by the Baban, Bilbas, Zerzan, and Shukriyan tribes living in the Sulaymaniya and Shahrezor area); and Zaza, which is characterized as "also a Kurdish language, but very different from the other three". Kurds from Zaza-speaking areas, he states, write in the Hakkârî dialect but speak their own dialect among themselves. He adds that, no matter how different this dialect may be, "it is not separate from the Kurdish language" (ji zimanê kurdî cuda nabe), and that the "foundations" of all these dialects are one and the same; by the latter claim, he appears to mean that basic terms, like those for "water", "bread", "come", "go", and the like, are identical. ${ }^{56}$

Presumably, Bayazîdî reproduces an existing folk-theoretical distinction between the Rawendî and the Hakkârî dialects here, but his distinction corresponds neither to the (equally folk-theoretical) distinction between the Botî, Mihemmedî, and Silevî dialects in Khanî’s Mem û Zîn (bayt 2480) nor to the modern philological and political distinction between the Kurmanjî, Badînî (or Bahdînanî), and Soranî dialects. Intriguingly, Bayazîdî nowhere mentions the forms of Goranî or Gûrani spoken and written at the Erdelan court, let alone the Lori and Lakki dialects spoken further south. This once again confirms the impression that he had little familiarity with conditions and developments in Southern Kurdistan.

53 Reproduced in Dost, Adat, 221-22.

54 It is not entirely clear whether by "Kurdish re'âya", Bayazîdî specifically means Kurdishspeaking Christians, and more specifically Armenians, or also includes non-tribal Kurds (whether Sunni Muslim or Yezidi) among them. But in ARE, he generally appears to use the term re'âya for Christians, and goran for sedentary and/or non-tribal Kurds: Dost, Adat, 226.

55 This would imply that Bayazîlî's own works are also written in a dialect different from that of his native Bayazîd (which forms part of the Rawendî group); a further study of the dialectal features of his writings, and of the question of early modern attempts at creating a written standard for Kurmanjî, however, awaits another occasion. 
In short, Bayazîlîs concept of the Kurdish language can hardly, if at all, be assimilated to those of philological nationalism - he does not appear to see it as the origin, basis, or criterion of a distinct identity, and he conceives of it in terms of purity, mixture, and corruption rather than in romantic terms of expression and organic growth. To the extent that Bayazîdî talks about the Kurds as a distinct nation or people, that is, he does so independently from the categories of modern Western philology or romantic nationalism.

\section{5 \\ Literature or Folklore?}

A second question to be discussed concerns the concept of literature implied in Bayazîdî's work. Some aspects of his writings appear to reflect or suggest a modern literary sensibility; for example, his summary of the tale of Mem and Zîn is clearly based on Ehmedê Khanî's written text rather than on any oral version of the story, but he strips the narrative of all mystical content and allusions. Thus, he paves the way not only for more secularized and nationalist readings of the epic but also for a secularized concept of literature or fiction. Accordingly, his writings, and in particular the collection of tales gathered in ${ }_{C R H}$, have led Hakim to call him "the true pioneer of Kurdish prose". ${ }^{57}$ Farhad Pîrbal has argued more specifically that Bayazîdî's tales, alongside his prose summaries of Mem û Zin and other texts, are not only among the oldest samples of Kurdish prose texts but also the first specimens of the Kurdish short story (çirok). ${ }^{58}$ The former claim appears to be largely correct, if one disregards a small but significant number of eighteenth-century didactic prose texts written exclusively for use by medrese pupils, notably Eli Teremaxî's Tesrîfa Kurmancî, Mulla Yûnus Khalqatînî's Terkîb $\hat{u}$ Zurûf, and a short medical text by Melayê Erwasî. The category of the short story, however, presupposes a modern notion of literature as essentially fictional, and this assumption does not appear to inform Bayazîlì's writings - witness the fact that he calls the tale of Jaubert's imprisonment in Bayazîd a hikâya, even though he clearly believes that the events he describes there had actually occurred.

Famously, Michel Foucault has emphasized the distinctly modern character of the concept of "literature", but he hardly discusses its specifically national character. According to him, the notion of literature as a specific, purely

57 Hakim, "Mem", 189.

$5^{8}$ Pîrbal, Bayazidi, esp. 8o. See also Hashem Ahmadzadeh, Nation and Novel: A Study of Persian and Kurdish Narrative Discourse (PhD dissertation, Uppsala University 2003), esp. $158 \mathrm{n}$. 
aesthetic modality of language independent of any representation or mimesis of an outside world, is new to the nineteenth century. ${ }^{59} \mathrm{In}$ this period, a neologism adabiyya/edebiyat, derived from classical adab, "humanistic learning" or "cultivation", but referring to literature in this objectified and national sense, was also introduced in the Islamic world, apparently first in Ottoman Turkish and subsequently in Arabic innovators and Persian. Late nineteenth-century Kurdish authors still use the term edebiyat; the present-day Kurmanjî term for "literature", wêje, appears to be an import from the Southern Sorani dialect and was only codified in Kurdoev's 1957 Kurdish grammar. ${ }^{60}$ Likewise, the term çîrok was used for "short story" for the first time in $1913,{ }^{61}$ and the Kurmanjî Kurdish neologisms for "poetry" and "prose" (respectively, helbest and pexşan), both likewise originating in Sorani, appear to be of an even more recent date.

In Bayazîlî, none of these romantic-nationalist categories of literature can be found - he consistently uses traditional Arabic terms like shi'ir and hikâya, rather than Kurdish neologisms, nor does any nationalized or nationalist notion of "literature" emerge from his Risaleyeke di behsa şấir $\hat{u}$ musannifê di Kurdistanê (Essay on the poets and authors in Kurdistan), which may well be the oldest source for discussing the history of Kurdish literature in existence. It is a brief discussion of the lives and writings of eight poets writing in Northern Kurdish in the 1860 Jaba collection. ${ }^{62}$ The first of these poets, Alî Harînî, is stated to have lived between 400 and $471 \mathrm{AH}$ (1009/10-1078/79 CE); the second, Shaykh Ahmed, better known as Melayê Cezîrî, is described by Bayazîdî as having fallen in love with the sister of the emir of Botan, and as having died in 556/1161. Bayazîdî dates the next poet, Feqiyê Teyran, a full two centuries later, even though he was in all likelihood a near contemporary of Melayê Cezîrî.63 We find few, if any, qualifications of an aesthetic nature here, beyond brief characterizations like that of Feqiyê Teyran's verse as "recherché and colourful" (mulamma' û rengîn).

The same holds for the brief remarks on Ehmedê Khanî, undoubtedly the best known among the poets listed in this text. ${ }^{64}$ Although Bayazîdî states that

59 Foucault, Mots, 313. Nichanian, Deuil, 83n., already observes that Foucault's "treatment of the ethnographic nation would require some elaboration".

6o Cf. the lemma wêje in Michael Chyet's Kurdish-English dictionary (New Haven: Yale University Press, 2003), 646.

61 Cf. Ahmadzadeh, Nation, 157-58.

62 Jaba, Recueil, 8-11Fr.; 13-16Kd.

63 Cf. D.N. MacKenzie, "Malâ-ê Jizrî and Faqî Tayran", in Yādnāme-ye Irāni-ye Minorsky, ed. by M. Minovî \& I. Afshar (Tehran: Tehran University Press, 1969), 125-30.

64 Bayazîdî further mentions a townsman of Khanî's, Isma'îlê Bazîdî (1065/1654-55 1121/1709-10), who, he claims, has written a Kurdish-Arabic-Persian glossary entitled Gulzar ("Rose Garden"), for use by children, but this text may have been lost. 
Khanî was the best loved of Kurdish poets, there is nothing to suggest that he thought of the latter's Mem û Zîn as anything like a Kurdish national epic, as Kurdish intellectuals from the later nineteenth century onwards would do. Instead, he just describes it as a poem "about a lover and a beloved". 65

On closer inspection, Bayazîdî can hardly even be said to have a notion of a national literature or a national history at all. To begin with, his is not the teleological or revivalist language of a national literary awakening; after Murâd Khan, he writes, there have been no more Kurdish poets, ${ }^{66}$ implying that the heyday of vernacular Kurdish poetry already lay in the past. Likewise, his brief description is a far cry from the historicist notion of a national literary history as it was becoming current in the nineteenth century - he talks of Kurdish poets, not of Kurdish literature. Thus, this short text may be characterized as the first "history of Kurdish literature" only with the proviso that Bayazîdî had a concept neither of "literature" (let alone a "national literature") nor of literary history that went beyond the bare chronological ordering of authors who happened to be writing in the Kurmanjî language.

Neither in this short text nor elsewhere is Bayazîdî any more concrete regarding Kurdish oral "folklore" than he is about Kurdish "literature". Most remarkably, he is completely silent regarding the oral literary traditions that have come to be seen as a proverbial part of Kurdish culture - witness Nikitine's and Vil'cevskiij's remarks on an allegedly uniquely Kurdish "hypertrophy of folklore". ${ }^{67}$ Rather, the short essay on Kurdish poets focuses on written texts rather than on sung performances, even though poems like Feqiyê Teyran's have long been used in folk songs. On the other hand, the narratives in $C R H$, qualified by Bayazîdî himself as hikâya, are, for the most part, neither short stories nor folk tales in the present-day sense; in fact, a good many of them are non-fictional and have a decidedly political character. They discuss contemporary events, like religious and tribal conflicts, and confrontations between local Ottoman rulers and tribal chieftains. They rarely explicitly address the recurring wars between the Ottoman Empire and Qajar Persia, or the increasingly frequent military confrontations with the expanding Russian Empire, although these unmistakeably provide the political and military context for some of his tales. Tale 39, in particular, refers or alludes to the ambivalent loyalty of Kurdish tribal leaders in the recurrent Ottoman-Persian wars. It relates how in 1235/1819-20, two Kurdish chieftains, Sulayman Agha of the Sipikî and Husayn Agha of the Zilan, come to the court of Abbâs Mîrza, the Qajar crown prince

\footnotetext{
65 Jaba, Recueil, $10 \mathrm{Fr} / 15 \mathrm{Kd}$.

66 Ibid., 11.

67 Cf. Nikitine, Kurdes, 255 .
} 
and military commander. There, however, they are insulted by a Persian dignitary, Zeman Khan, who calls them "whores" (qehbe) ${ }^{68}$ Sulayman is so enraged by this insult that in the subsequent Battle of Alashkir, he turns against the Qajars and captures and personally decapitates Zeman Khan, along with a thousand of his soldiers.

Another significant tale in this respect is the story of Jaubert's 1805 imprisonment by Ibrahim Pasha in Bayazîd. It is instructive to compare this hikâya with Jaubert's own version of events. ${ }^{69}$ Jaubert's narrative largely reproduces the stereotypical image of the Kurds as thieves and robbers who, despite claiming a tradition of considering hospitality a sacred duty, are willing to betray even their guests, with the significant exception of the noble prison ward who saves Jaubert's life. For obvious reasons, it avoids any hint that the pasha's suspicions against his French visitor (who, after all, was on a secret mission to broker an alliance between Russia and Qajar Persia, the Ottomans' two most important regional enemies) might be justified. Bayazîlî's version, remarkably, largely reproduces Jaubert's framing of the story, which emphasizes that the friendship between Jaubert and his prison ward transcends the political and diplomatic confrontation between the pasha and a French diplomat on a secret mission in enemy territory. There are a number of minor divergences, however, which may suggest that Bayazîdî also based his account on local (and, probably, oral) Kurdish sources. Thus, the brave prison ward, whom Jaubert calls Mahmûd, appears under the name of Qasim Agha here. It is, of course, very well possible that Bayazîdî, through Jaba, was himself familiar with Jaubert's travel account. He must certainly have had access to the latter's Turkish grammar, as it was from this work that he translated a number of Turkish proverbs into Kurdish. ${ }^{70}$ Bayazîdî clearly signals his disapproval of the pasha's behaviour; by contrast, Jaubert's noble qualities, he writes in conclusion, have become proverbial in Kurdistan, and most Kurds in Bayazîd know his story (ekserê ekrâdêd bajêrê pê dizanin). ${ }^{71}$

In other words, and despite appearances, both the philological concept of literature and the ethnographic concept of folklore or folk tales are absent from Bayazîlî's writings. All this suggests that the category of "Kurdish folklore" or "Kurdish folk tales" was not simply a given of Kurdish everyday life but had to be constructed - apparently, with some effort - by foreign scholars. Bayazîdî's collection of tales and his comments on the cultural customs of the Kurds mark a very early stage in this process.

68 Jaba, Recueil, 103, discreetly renders this term as "canaille".

69 Jaubert, Voyage, esp. pp. 37-73.

70 Lerch, Forschungen, vol. I: $\mathrm{X} ; 25$ of these proverbs are reproduced ibid., 92-97.

$71 \quad$ Jaba, Recueil, ${ }_{102} \mathrm{Fr},{ }_{119 \mathrm{Kd}}$ 
These tales and other writings also give an idea of Bayazîdî's political loyalties. He repeatedly accuses tribal chieftains or aghas of injustice $(z u / m)$ against both Kurdish and Christian peasants, and he implies that the ongoing centralization of Ottoman government is a beneficial development for the local population. Thus, in $A R E$, he mentions the oppression and injustice (cebr $\hat{u}$ te'eddî) of the nomadic Kurds against both sedentary villagers (apparently assumed to be Muslim or Yezidi Kurds) and Christian réâya. This injustice, he continues, had been brought to an end only in recent years, as a result of the reforms initiated by Sultan Abdülmecid I: thanks in particular to the creation of the asâkiri nizamiyya [i.e., the new Ottoman army formed in 1841], he writes, the (tribal) Kurds have gradually been 'set aside' (berteref bûyin), and oppression and injustice have gradually disappeared. ${ }^{72}$ Likewise, tale 40 of $C R H$ relates the story of Hafiz Agha, a strongman of the Levend, or Ottoman irregular cavalry troops, who, in systematically oppressing the réâya and revolting against the provincial governors, commits all kinds of violence and injustice (cebr $\hat{u} z u l m$ ). Through clever scheming, however, the Kurdish mîr Shemdîn of Akra, and even more importantly his wife, Meleke, succeed in ambushing and killing Hafiz Agha and subsequently send his head to the vali of Mosul. Such and similar stories suggest that Bayazîdî viewed Ottoman military reform and governmental centralization as a beneficial process that brought injustice in the Kurdish provinces to an end - surely, a rather optimistic reading of the local developments of that period. The removal of the Kurdish mîrs in the 1840s, in particular, had actually had the effect of increasing oppression, both through new - and higher - taxation and through increased lawlessness and insecurity at the hands of marauding tribes that now faced even fewer constraints than before. Bayazîdî, writing in the late 185 os, is unlikely to have been wholly unaware of these negative consequences; perhaps, then, we can construe his words as being ideologically driven, and as expressing support for centralized and centralizing Ottoman rule.

Now let us turn to Bayazîdî's discussion of more recognizably ethnographic topics, like gender relations, tribal structure, and ethnic identity. ARE may well be said to be the first extended ethnography of Kurdish customs, if we disregard the rather less comprehensive earlier observations by Ottomans like Evliya Çelebi and foreigners like C.J. Rich and Carsten Niebuhr. We should specify more concretely, however, the kind of ethnography to be found here. It would

72

Dost, Adat, 114-15. 
be an exaggeration to infer that $A R E$ is based on anything like ethnographic field research; rather, it presents a number of cultural stereotypes and Kurdish self-perceptions, most of which appear to be based on hearsay and on local folk beliefs rather than on participant observation or systematic data collecting. Thus, Bayazîdî's descriptions of various local Kurdish habits or customs in tribal warfare, marriage rites, games, horse breeding, and so forth, follow each other in no clear order of argument or exposition. The text is also somewhat repetitive: Bayazîlî repeatedly returns to previously discussed topics, like weddings and games. Finally, the text appears to show traces of the conversations that Bayazîdî and Jaba must have had, most clearly visible in repeated statements that, in some particular respect, the Kurds are "just like the French" (wekû ifrancan or wekû miletê Efrenciyê). ${ }^{73}$ There is no evidence that Bayazîlî was familiar with any contemporary written work on the French or originating in France, let alone evidence of any travels to that country; he is more likely to have acquired whatever knowledge he had about contemporary French customs from his conversations with Jaba rather than from any French book, or even from a work like Rifā‘a al-Ṭahțāwì's Takhlīṣ al-ibrīz ilā talkhīṣ Bārìz, even though the latter had been translated into Turkish soon after its first Arabic publication in $1834{ }^{74}$

The most remarkable among these comparative remarks is undoubtedly Bayazîlî's claim that Kurdish women are as free (serbest) as French women, because they never get kidnapped: "Their women and daughters are not kidnapped by anyone. They are free just like the French people" (jin û keçêd wan ji kesînarevin. Wekû miletê Efrenciyê ew jî serbest in).${ }^{75}$ Here, we have one of the earliest mentions of the modern Kurdish self-image that Kurdish women are freer than women from among the neighbouring Muslim peoples. He immediately adds, however, that if a woman does something wicked, she will inevitably be killed (îlla egeryekêji wan şola xirab kirîn, çare nînin elbette ewê dikujîn) - which indicates that the alleged freedom of Kurdish women may in fact be rather restricted. ${ }^{76}$ Elsewhere, he states that Kurdish men did not traditionally practise sodomy (liwât), and that they had only recently started drinking alcohol, due to the pernicious influence of the Turks.

It should be noted that Bayazîdî's knowledge is limited largely to Northern Kurdistan. Thus, the list of tribes he presents, like most of his other writings, focuses on the North, and nowhere in his preserved writings does he betray

73 Ibid., 46, 54, 99 .

74 Rüstem Besim (tr.), Seyahatname-i Ibn Rifaa [Tercüme-yi Seyahatnâme-yi Pâris]. Cairo, Bulâq 1839 .

75 Dost, Adat, 46.

76 Ibid., 107-08. 
any detailed familiarity with Kurdish inhabited areas south of the Bahdinan region. He does note, however, a number of differences between the Kurds living in the regions of Bayazid, Kars, Erzurum, and Van, and those living further South, in Hakkârî, Botan, Bahdinan, and Amadiyya, writing that among the Southern Kurds, more people own guns, and distinct relations obtain between tribal and sedentary populations. ${ }^{77}$ Apart from the brief mention of the Sulaymaniya dialect ${ }^{78}$ in the introduction to the $T c K$, however, he nowhere elaborates on the tribes, tribal confederations, or emirates of Southern Kurdistan (except, possibly, in chapter 6 of that lost chronicle), let alone the linguistic and historical particularities of Hawramî or Goranî varieties, in particular as spoken and written at the court of Erdelan, even though the latter is mentioned in the Sherefname.

Bayazîdî's writings are informed by a generic distinction between urban and rural, and between tribal-nomadic and sedentary. The Muslim Kurds in the cities, he writes in the introduction to $T C K$, "are good Muslims; among them are learned and brave "ulamâ". ${ }^{79}$ However, this does not boil down to a simple binary opposition between Islamic learning articulated in the Arabic language and local Kurdish customs, or between urban Arab-Islamic orthodoxy and rural Kurdish ignorance - he also describes the formerly flourishing tradition of rural religious learning in the Kurdish language. In $A R E$, Bayazîlî does not hint at, let alone discuss in any detail, any such written literary tradition or a vernacular literate tradition of learning among the Kurds, but he was clearly aware of its existence, as appears from his two short texts on Kurdish poets and Kurdish learning already dicussed above. His strict separation between a learned vernacular literature and an ignorant oral culture may be a factor preventing him from seeing the Kurds, like the modern Armenians, as a "philological nation", defined by a shared language, oral tradition, and literature, as discussed by Nichanian. This suggests, once again, that his methods, conceptions, and normative assumptions are clearly neither those of modern (orientalist) philology nor those of romantic folklore-oriented nationalism.

Regarding social organization, Bayazîdî's category of Kurdishness is as inclusive as it is in linguistic terms. He nowhere gives any hint of considering the tribal (rewend) and the sedentary non-tribal (yerlû, goran) population groups as different groups, nations, or races, in the way that Claudius James Rich and, possibly, some of the latter's local informants in Sulaymania had done. According to Rich, the Goran or Miskên were distinguished by their language, physical

\footnotetext{
77 Ibid., 127, 117 .

78 Ibid., 221.

79 Ibid., 229.
} 
traits, and customs from the Kurds proper, and formed the region's original population, which had been overrun and reduced to a subordinate status by invading Kurdish tribes. ${ }^{80}$ Bayazîlîs remarks, admittedly focusing on NorthEastern rather than Southern Kurdistan, offer little, if any, support for this theory. In $A R E$, the term Goran is employed only once, without any clear ethnic significance, ${ }^{81}$ let alone any connection to the Goranî or Hawramî dialects, and this single occurrence appears in the context of a generic opposition between ekrad, here identified with nomadic (rewend) Kurds, and yerlû, or sedentary, peasants. The former, Bayazîdî adds, call the latter Goran, considering them weak and cowardly, and rarely intermarrying with them. He does not, however, mention any linguistic, genealogical, or racial distinction between the two, and he explicitly denies that any opposition exists between tribal rewend and sedentary, non-tribal goran in the regions of Hakkârî, Botan, Amadiye, and Soran. ${ }^{82}$

Religion and Religious Groups

Bayazîlî's writings on religion among the Kurds are equally revealing of his distinct categories. He has no clear-cut notion, let alone a modern anthropological or philological concept, of religion. He uses the term millet, which indicates not a body of doctrines or ritual practices, but rather a group of people; this term, in fact, is ambiguous, denoting what in modern vocabulary would be called either "religion" or "nation". ${ }^{83}$ Moreover, he nowhere hints at religious beliefs or customs he sees as typical for, or originating with, the Kurds. Thus, Newroz, the celebration of the spring equinox celebration that in later decades would come to be seen as a specifically Kurdish national holiday, is notably absent in $A R E .^{84}$ In fact, Bayazîdî's description of Newroz in his prose summary of Mem û Zîn suggests that he not only does not see the festival as specifically Kurdish, but is in fact actively trying to Islamicize it, as he emphasizes that it is in complete agreement with religious laws.

80 Claudius James Rich, Narrative of a Residence in Koordistan, 2 vols. (London: J. Duncan, 1836); cf. Martin van Bruinessen, Agha, Shaykh, and State: Social and Political Structures of Kurdistan (London: Zed Books, 1991), esp. 109-21.

81 Dost, Adat, 116.

82 Ibid., 117 .

83 More generally, barring significant exceptions like al-Fârâbî's Kitâb al-milla, premodern and early modern authors do not use terms like dîn, milla, etc., to refer to the religious beliefs of particular groups of people.

84 Dost, too, observes that Bayazîdî apparently does not see Newroz as a specifically Kurdish festival; cf. Dost, Adat, 27-28. 
Both in the tales collected in $C R H$ and in the preface to $T C K$, Bayazîdî expresses remarkably mild opinions concerning Christians and Yezidis. It is possible that he moderated his comments on, for example, Armenians, Nestorians, and Yezidis with an eye on his Russian and Christian readership, but we have no way of knowing. Here and elsewhere, he virtually identifies Christians ( fellâh) with the re'âya or "flock", even though the latter could also include Muslim Ottoman subjects who did not belong to the askerî class just as well as dhim$m \hat{\imath}$ s. In the introduction to $T c K$, he writes that "in Kurdistan, there are around 70,00o houses [i.e., families] of Armenian re'âya, 15,00o houses of Nestorians [Assyrians], and 200 houses of Jews". He adds that "the reâya of Kurdistan speak Kurdish", 85 and even that their women and children know no language other than Kurdish, implying that only Armenian males with some degree of education knew the Armenian language (presumably, the classical language variety usually called Grabar); only the Nestorians are listed as having a language of their own. ${ }^{86}$ More generally, he claims that the "re'âya and Armenians in Kurdistan are in all respects like the Kurds". ${ }^{87}$ Despite this apparent lack of linguistic and cultural differences, however, Bayazîdî nowhere classifies Christians as Kurds. In the introduction to $T C K$, he further writes that Christians "live well together with the Kurds", with whom they exchange kirivs, or godfathers at circumcision ceremonies (implying a belief that Christian re'âya are circumcised). ${ }^{88}$

The Yezidis are a rather more complicated case. Although Bayazîdî is clearly reluctant to write about them, he generally appears to list them alongside Sunni Kurds, or as a specific taîf $f$ among the Kurds, without hesitation. ${ }^{89}$ In ARE, he does not give any detailed descriptions of Yezidi customs, but merely characterizes them in the briefest of manners:

In Kurdistan, there is also the Yezidi group (ta't fe) of the Kurds, who are not Muslims but Yezidis. Their rites and ceremonies and manners and

$85 \quad$ Ibid., 226 .

86 Ibid., 236.

87 Ibid., 226, 236.

88 Ibid., 236.

89 Cf. e.g. Ibid., 134. Remarkably, he nowhere explicitly characterizes the tribes listed in his Risâla as either Kurd or Kurmanc. He includes both Sunni and Yezidi tribes, apparently believing that both qualify as Kurdish (Jaba: Recueil, 1-7). No tribes are listed as specifically Christian, even though in particular Hakkârî province is known to have harboured Nestorian tribes in this period. Elsewhere, however, he states that no Kurd has a madhhab other than the Shafi'ite one, implicitly excluding both Yezidis and Christians. Dost, Adat, 130 . 
customs and ceremonies are distinct. This group worship Iblîs and call the Satan 'Melek Tawûs'; but their language is Kurdish.

Li Kurdistanê jî ekradan ta'îfeya êzîdiyan jî heyîn ku musulman nînin, êzî̀ ne. Resm $\hat{u}$ ayin $\hat{u}$ 'urf $\hat{u}$ adet $\hat{u}$ ayina wan jî cihê ne. Ew ta'îfa bi perestiya Iblîs dikin û ji şeytan re dibêjin Melek ê Tawûs. Lâkin zimanêd wan jî kurdî ye. ${ }^{90}$

He clearly has his information from Muslim sources hostile to the Yezidis, as Yezidis themselves would categorically reject the identification of Melek Tawûs with the Satan (Sheytân). His brief comments betray a clear reluctance to elaborate; in fact, he refuses to provide more details on this sect, claiming that doing so would render his book inordinately long.

Some further information about the Yezidis and their relations with their Sunni Muslim Kurdish neighbours, however, appears in tale 7 of his hikâyas, which tells of the enmity between the Yezidi tribes and the religious scholars (fuqahâ) in Kurdistan. Here, he relates how one mullah, Mehmedê Qulpî, was captured near Bayazîd by a group of Yezidi horsemen, and how their pîr vainly tried to convert him to their faith by force. This story's main event is, of course, virtually the reverse of what was actually happening during the nineteenth century, when both Ottoman officials like major Abdulkadir and Sunni Kurdish leaders like Mîr Muhammad of Rawanduz and Bedir Khan Beg of Botan conducted military campaigns against the Yezidi tribes of the Sheykhan and Sinjar areas; some of these raids involved attempts to forcibly convert Yezidis to Sunni Islam.

Finally, in $A R E$, Bayazîdî mentions that, among every Kurdish community, there are a few houses of Gypsy musicians (mitrib): "They have a language of their own, which others do not understand and which they speak at home; with Kurds, however, they speak Kurmancî." ${ }^{11}$ He adds that no Kurds intermarry with them; unlike Yezidis, that is, gypsies do not qualify as Kurds in Bayazîdî's ethnic classification.

Bayazîdî appears to be as critical of Muslim clerics as he is tolerant of Christians. Although he himself obviously belonged to the men of religious learning, some of his texts have a decidedly anticlerical character. In tale 2 of $c R H$, he notes that Kurdish religious scholars do not consider stealing from Armenians a crime, and in $T C K$, he states that Muslim Kurds do not think it a sin to kill a

90 Bayazîdî, $A R E$, 1913-1918; Dost, Adat, 134. Incidentally, this is virtually the only time that Bayazîdî characterizes the Kurdish language as kurdî rather than kurmancî.

91 Dost, Adat, 133. 
Yezidi, ${ }^{92}$ implying disapproval in both cases. Tale 3 describes the avarice of a Kurdish mullah who preaches his congregation to give away half of their possessions to the poor but is enraged to find out that his wife does the same with his own (admittedly, meagre) possessions. Such advice, he says "is for others, not for myself", adding, "I preached to the people so that they would give me their surplus clothes and bread" ( $\min$ wesanê we'ez kirin ku xelq cilêd xwe ye zêde û nanê bidine min). Bayazîdî concludes this story with the comment that such double standards are typical of "scholars of all religions" (xwendêd hemi milletan) ${ }^{93}$

Bayazîdî displays a tendency to describe the customs he views as specifically Kurdish in an explicitly normative, and pejorative, vocabulary of deviations from religious orthodoxy, and more specifically as forms of ignorance (jâhiliyya). Thus, it is in terms of ignorance that he describes the practices of magicians (efsûncî), astrologists (mineccim), and fortune tellers (pîldar, tasniher). ${ }^{94} \mathrm{He}$ even condemns the Kurdish habit of treating bread as something holy: "The majority of the ignorant ones among the Kurds believe bread is an object of faith" (Ekserêdcuhelayêdwanekradan, me'azellahnanî̀mandizanin). ${ }^{95}$ For him, however, the term câhil does not seem to have any clear temporal connotation of pagan or pre-Islamic customs. Thus, he nowhere presents these customs as in any way primitive, primordial, or timelessly Kurdish, in the way Armenian philology allegedly construes a pagan Armenian past as "native". Repeatedly, he also characterizes contemporary rural, tribal, and nomadic Kurds as ignorant (câhil), partly because of their reliance on shaykhs: "The Kurds, in their ignorant form of belief (itiqâdê cahiliyye), have a strong faith in their shaykhs. Every group or section (millet $\hat{u}$ tayiffek) of them has a shaykh of its own." 97

But Bayazîdi's criticisms target not only the rural ignorant laity but also the religious leaders. Most of the Kurdish shaykhs, he writes, are ignorant and uneducated (ekserêd şêxêd wan câhil $\hat{u}$ nexwendîne).$^{98}$ Although similarsounding criticisms of the ignorance of Sufi shaykhs can be found among both Islamic modernists and secular modernists of around the same period, Bayazîdî seems to see this ignorance not in modernist terms of progress and stag-

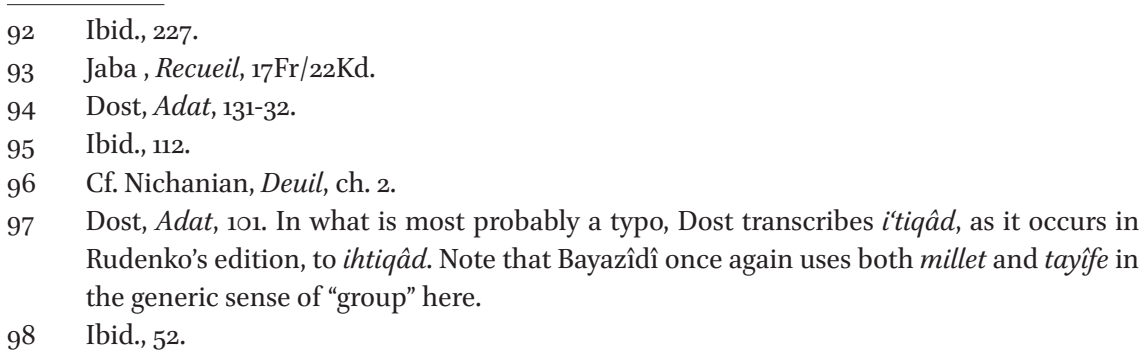


nation, but rather as an indication of the decadence of his own age. Earlier generations of shaykhs, he writes, were pious and venerable (salih $\hat{u}$ şêx bûne), but their successors are ignorant and uncultivated (cahil $\hat{u}$ bê edeb). ${ }^{99}$ These remarks are in line with his comment elsewhere that the virtual disappearance of learning in Kurdistan is a sign of the imminent end of time (elametê axirî). ${ }^{100}$ Clearly, Bayazîdî's sense of historical temporality is shaped by religious eschatology rather than by nationalist notions of progress and emancipation. It would therefore be an overstatement to characterize Bayazîdî as a secular or modernist author, but his critical attitude towards his co-clerics' ignorance and corruption is nonetheless significant. Incidentally, it should be noted that he nowhere refers or alludes to the religious reform movements that swept through the early nineteenth-century Ottoman Empire, such as the Wahhâbî and the Khalidiyya Naqshbandî movements, but it seems unlikely he was unaware of them. ${ }^{101}$

\section{8}

History

Finally, let us explore the kind of historiography Bayazîdî writes. He explicitly states that his translation of the Sherefname was made at the request, and with the support, of "Monsieur Jaba" (bi istidâ û Xwaheş û himmeta Misyo Jabayî). ${ }^{102}$ Perhaps it was also Jaba who had bought the manuscript copy of the Sherefname which Bayazîdî used for his Kurdish translation, but there are no concrete indications of this. ${ }^{103}$ One might think that Bayazîlìs simplified Kurdish-language version reflects a tendency, also visible in other languages of the Ottoman Empire during that period, to develop simpler registers of vernacular prose language that contain fewer Arabic and Persian loan words and phrases and are thus more accessible to less thoroughly educated readers. But

\footnotetext{
$99 \quad$ Ibid., 101.

100 Jaba, Recueil, 14.

101 Jaubert, Voyage, 15, already mentions the presence of a number of Wahhâbîs in Erzurum in 1805, suggesting that the Wahhâbî movement was very active in different parts of the Ottoman Empire from early on.

102 Dost, Adat, 211.

103 The Kurdish translation of the Sherefname diverges on various points from the original: not only does Bayazîdî tacitly change various proper names and place names, his translation also omits various passages, in an apparent attempt to simplify Bidlîsî's "ornamented style". Musaelian, "First", 5-6. Despite the tables systematically confronting the Persian and the Kurdish text in Kurdoev \& Musaelian, Tavarih, 17-45, however, a detailed comparison of the style and content of these two works has not yet been made.
} 
again, the fact that this text appears to have been written exclusively for Jaba makes such hypotheses, attractive as they may be, rather speculative.

Bayazîdî's own sequel to the Sherefname, the $T C K$, covers the period of $1200 / 1785$ up to $1274 / 1857-58$, the year in or before which it was actually written. The existing sources give no clear reason why this work starts in $1200 \mathrm{AH}$, long after the end of the period covered by Sheref Khan Bidlîsî. The table of contents of this work, reproduced by Dost and Avci from Vasilyeva, ${ }^{104}$ lists eleven chapters dealing with different Kurdish emirates or districts, opening with a chapter on the vilayet of Erzurum, and includes chapters on regions like Bayazîd (where Bayazîdî himself was born), Rawanduz (presumably, dealing with the rise and fall of the nineteenth-century strongman Muhammad Pasha), and Botan (presumably, focusing on Bedir Khan Beg's rule), and on the Russian siege and temporary occupation of the city of Kars. The inclusion of these topics makes the loss of this work all the more deplorable. A separate chapter is devoted to "Azerbaijan" (i.e., the Kurdish regions falling under Persian rule). Remarkably, Bayazîdî appears not to give any detailed attention to the Kurdish principalities south and east of Rawanduz, like the Baban and Erdelan dynasties. About the reasons for this omission, and about the written and oral sources at his disposal, we can only speculate.

Superficially, Bayazîlî might seem to be engaged in the kind of nationalist historiography typical of nineteenth-century Europe. For example, in the onepage preface to his translation of the Sherefname, he writes that

Every past people and nation have a separate history and a known noble descent and lineage, except for the people of the Kurds, who until the year $1000 \mathrm{AH}$ [1591-92 CE] did not have an independent history.

Kafeyê tewâyîf û milelêd borî her yekî cuda cuda tewarîx û meşhûr heseb $\hat{u}$ neseb heyin, îla ku tayifeyêd kurdan heta tarîxa hezarê hicretê ewan tewayifêd ekradiye bi xoser tewarîx tunebune. ${ }^{105}$

In the same year of $1000 \mathrm{AH}$, he continues, Sheref Khan of Bidlîs wrote a chronicle of the Kurdish rulers and tribes in the Ottoman and Persian Empires, but of this work, only two or three very expensive manuscript copies, which cost up to a thousand qurush, circulate in all of Kurdistan. Bayazîn's further comment that the Sherefname was written in Farsi ${ }^{106}$ makes it tempting to see him

\footnotetext{
104 Dost, Adat, 216; Avci, Adat, 25-26; cf. Vasilyeva, Kniga.

105 Dost, Adat, 211.

106 Ibid.
} 
as a romantic nationalist who believes that a truly national history should be written in the national language, and that the Sherefname should therefore not be considered a genuine national history. But his own motivation for writing a history in the Kurdish language may equally well, and in fact more probably, have been the practical concern that, because of both its language and its price, this work was out of reach for the Kurdish-reading public, which at that time consisted primarily of medrese-educated males and local rulers; or he may have had an even more down-to-earth motive in the fact that a Kurdish translation of Sheref Khan's work had been commissioned by Jaba.

What does become clear from Bayazîdî's writings, however, is that the year 1000/1591-92 occupies a special place in his conception of Kurdish history. It was around this year, he writes, that Sheref Khan wrote the first Kurdish chronicle; ${ }^{107}$ that Eli Teremaxî pioneered the writing of Kurdish as a language of learning; ${ }^{108}$ and that Ehmedê Khanî settled in Bayazid, where he was to compose the first major mathnawî poem in Kurdish ${ }^{109}$. These claims vary in their degree of accuracy: the date of $1000 \mathrm{AH}$ is approximately correct in the case of Bidlîsî, whose Sherefname is dated 1005/1597; it is possible, but not very plausible, in the case of Teremaxî, whose undated Tesrîfa Kurmancî is not attested before the late eighteenth century; ${ }^{110}$ and it is clearly false in the case of Khanî, who himself explicitly indicates his year of birth as 1061/1650, and who writes that he has finished his Mem $\hat{u} Z \hat{\imath} n$ at the age of 44 - that is, in the year 1107/1695:

Lewra ku dema ji xeybê fek bû/Tarîx-i hezar $\hat{u}$ şêst $\hat{u}$ yek bû/Îsal-i gihişte çil $\hat{u}$ çaran.

Because when he entered this world/The date was one thousand and sixty-one [i.e. 1650 CE]/ He became forty-four this year.111

Bayazîdî's error concerning Khanî's date of birth is all the more surprising as his prose rendering of the tale of Mem and Zîn is demonstrably based on Khanî's text rather than on any oral version of the story. It suggests that we

\footnotetext{
107 Ibid.

108 Jaba, Recueil, 12.

109 Ibid., 9 .

110 The oldest possible reference to this text that I have come across occurs in Mullah Yûnus Khalqatînî's late eighteenth-century Terkîb û Zurûf (ed. Emin Narozi, Stockholm: sARA, 1996), 29. It should be added, however, that not even this remark unambiguously refers to Teremaxî's work.

111 Ehmedê Khanî, Mem û Zîn, bayt 2654-2655 (transl. S. Saadalla).
} 
should take Bayazîlî's use of the year $1000 \mathrm{AH}$ as no more than a convenient, or conventional, demarcation of a significant development in Kurdish history. More importantly, it also suggests that he was well aware of the vernacularization of Kurdish in the not too distant past, and of its cultural-historical significance.

This makes it tempting to view Bayazîdî as a modernist who thinks of this vernacularization process in terms of historical progress, emancipation, and national awakening. But we should resist this temptation. Not only is the revivalist vocabulary of liberation or religious or national awakening after a centuries-long slumber entirely absent from his writings; he notes the historical significance of the year $1000 \mathrm{AH}$ but nowhere describes it as marking a radical break, rupture, or revolution, or even as an example of cultural innovation (tajdid) or reform (ișläh), the conventional terms for significant change wrought by cultural or religious innovators (mujaddids). On the other hand, Bayazîdî no more betrays a cyclical view of history (as can be found in, most famously, Ibn Khaldūn) than he gives any hint of a belief in historical progress. Instead, he sees his own era as marking a substantial cultural decline, not with respect to any divinely sanctioned origin or any mythical Golden Age, but with respect to the more recent past. Thus, he claims that after Murâd Khan (1150/1737-38 - 1199/1784-85), the eighth and final poet discussed in his short overview, "no poets have emerged from among the Kurds until now" (paşê wî̀ji kurmanciyan aydî şấir pêda ne bûye heta niha). ${ }^{112}$ Likewise, he writes in his introduction to Teremaxîs Tasrîf:

Nowadays, madrasas, teachers and learning have disappeared almost entirely in Kurdistan, or have at least become quite rare. Surely, it is a sign of the end of the world when one sees the sciences and the learned men diminish.

Niha êdî medrese $\hat{u}$ 'ulemâ $\hat{u}$ khwendîn di Kurdistanê da qewî kêm bûye... elbette elâmatê axirîye ku 'ilm û 'ulamâ nuqsan dibin. ${ }^{113}$

Earlier, he adds, schools could be found all over Kurdistan, in all towns, villages, and hamlets, and both rulers and inhabitants protected the schools and the learned men.

Given the scarcity of sources, it may be difficult if not impossible to determine whether these remarks are factually correct. It is tempting to link his

112 Jaba, Recueil, $11 \mathrm{Fr} / 16 \mathrm{Kd}$.

113 Ibid., $14 \mathrm{Fr} / 19 \mathrm{Kd}$. 
laments to the broader social and political upheavals of the time, like the disappearance of local court patronage, Ottoman attempts at centralization, and Russian imperial encroachment. But although he notes these developments, he does not himself appear to see them as actual causes of Kurdish cultural decline. More to the point in the present context is the sense of historical time implicit in Bayazîlî's pessimism, which appears to amount neither to a cyclical temporality, as in Ibn Khaldūn's Muqaddima, nor to a notion of linear progress, as may be found in modernist and/or nationalist historians. Nor does it seem based on modernist concepts of "progress", "civilization", or "evolution"; rather, it reflects a conservative belief in the decline of morals paired to an eschatological (and, one may perhaps add, conventional religious) expectation that the end of times is imminent.

\section{$9 \quad$ Kurdish and Russian Learning}

As suggested above, Bayazîdî's writings amount to a somewhat hybrid genre. They not only mark an important moment in the vernacularization of Kurdish but also belong to an early chapter in the history of Russian orientalism. To all appearances, they were never intended for a Kurdish audience, but were commissioned by, and composed exclusively for, the Russian consul, Auguste Jaba. As such, they fit into the broader pattern of early Russian oriental studies - in the mid-nineteenth century, Russian scholars or officials (more often than not working directly for the imperial Russian state) would specifically commission written works from local scholars among various Eastern peoples. ${ }^{114}$ The authors of these texts are not precisely "native informants" in the standard sense of the word - they were not illiterate, and could successfully claim some form of local epistemic authority. But in the process of incorporating their writings into Russian orientalist learning, this authority was clearly and unequivocally rendered subordinate to that of Western scholars.

The first Russian philological and folkloric explorations of the Kurds, as those of other peoples in the empire, were purely in the service of language acquisition and were less concerned with what was specific or unique to Kurdish customs or culture. Thus, the 44 "basic sentences" produced in Lerch's Forschungen are in fact Kurmanjî and Zaza translations of the sample

114 Cf. Vera Tolz, Russia's Own Orient (Oxford: Oxford University Press, 2010), esp. 159. For comparable studies on learned men among other Muslim peoples living under imperial Russian rule or influence, see also Michael Kemper, Sufis und Gelehrte in Tatarien und Baschkirien (Berlin: Klaus Schwarz Verlag, 1998); Allen Frank, Bukhara and the Muslims of Russia: Sufism, Education, and the Paradox of Islamic Prestige (Leiden: Brill, 2012). 
sentences contained in Bacmeister's famous 1773 Idea et desideria; the stories are in fact translations from Dieterici's and Letellier's collections of Turkish folk tales; and the 25 Kurdish proverbs he reproduces are simply Bayazîlî's translations of Turkish sayings included in Jaubert's 1823 Turkish grammar. The text even includes a translation of a Finnish rune inscription. ${ }^{115}$ These translations into local languages, too, are a regularly recurring phenomenon of early Russian oriental studies. One encounters various specifically commissioned translations of famous works of Persian literature, first and foremost Sa'dî's Golestan, into local vernacular languages, written with the apparent purpose of facilitating the acquisition and systematic philological study of these languages by Russian scholars who already have a command of Persian. Thus, Lerch in his discussion of the ongoing project of a Kurdish translation of the Golestan, also mentions an "Afghan" (presumably, Pashtun) and a Mazanderani rendering of that work commissioned by Russian scholars. Ironically, this use of the Golestan for facilitating the learning of vernaculars closely mirrors the use of Sa'dî's book among some of these very same peoples to learn Persian. ${ }^{116}$

The importance of Russian-imperial and Soviet scholarship for the more recent revival of interest in Bayazîdî can hardly be overstated. In fact, most, if not all, recent Kurdish-language editions of Bayazîdî's works are transcriptions, translations, and/or photographic reprints of earlier Russian and Soviet publications. ${ }^{117}$ Yet, in many earlier Russian writings, the role of Bayazîdî and other local scholars like him is curiously downplayed. This holds especially for writings by native scholars on vernacular languages, which were generally seen by nineteenth-century European scholars as at best a source of raw linguistic material yet to be properly analyzed and rendered academically respectable by Western scholars, and at worst a cause of confusion, as they were held to be based on inadequate linguistic doctrines and methods of transcription. Thus, Eli Teremaxî's Serfa Kurmancî, a short work of morphology copied by Bayazîlî for Jaba, was dismissed by the committee of the Russian Academy of Sciences, that had been put in charge of publishing Jaba's materials, as being a derivative

115 Lerch, Forschungen, IV, X, xx; cf. H.L.C. Bacmeister, Idea et desideria de colligendis linguarum speciminibus (St. Petersburg: Akademija Nauk, 1773); F. Dieterici, Chrestomathie ottomane (Berlin: Reimer, 1854); A.V. Letellier, Choix de fables, traduites en turk (Paris: Dondey-Dupré, 1826); P. Amedée Jaubert, Elements de la grammaire turke (Paris: Imprimérie royale, 1823), esp. 121-37.

116 Lerch, Forschungen, v.

117 This holds for, among others, Izoli's, Dost's, and Avci's editions of ARE; Avci's edition of $C R H$, and Dêreşi's edition of $T C K$. 
work of secondary interest, even though it is, in all likelihood, both the oldest Kurdish grammar and the oldest Kurdish prose text in existence. ${ }^{118}$

Lerch's Forschungen is similarly dismissive of Kurdish vernacular learning. The introduction to this work presents a quotation from Bernhard Dorn, who had also been Jaba's teacher, praising Jaba's hodja and main informant, who can hardly be anyone other than Mela Mahmûd, as "an educated Kurd" (einen gebildeten Kurden) who "knows our wishes". 119 Lerch, however, expresses his misgivings about the linguistic usefulness of texts written in the Arabic Persian script by local educated Kurds. Thus, he winds up giving Jaba more credit for the transcriptions than he gives the anonymous mullah for writing in the Arabic script without undue interference from Turkish or Persian, mentioning his lingering doubts about the usefulness of Kurdish texts "from the pen of a Kurd who was educated in his own way". ${ }^{20}$ The Kurmanjî texts received from Erzurum, he writes rather condescendingly, have exceeded his expectations - they have been written by a literate and learned (schriftkundige) Kurd, but "regardless of the fact that they are translations from Persian and Turkish, their author has not fallen into those extremes which I had feared on the part of a Kurd". ${ }^{121}$ Present-day readers will be struck by Lerch's condescending tone, and by his assumption that texts by a provincial Kurdish scholar should be expected to be full of errors and "extremes".

Another area where Bayazîdî's efforts appear not to have been given due credit is in the creation of a full-fledged Kurdish dictionary. The precise extent of Bayazîdî's contributions to what would be published as Jaba's and Justi's Kurdish-French dictionary ${ }^{122}$ is difficult if not impossible to establish, but they appear to be systematically downplayed by Justi, who in his introduction merely writes that the forms in Persian-Kurdish script have been written by "a Kurdish Mullah" (undoubtedly Bayazîdî). He adds that this mullah has made numerous errors (e.g., by confusing the hamza and the 'alif, $k$ and $q$, and plain and emphatic $s$ and $t$ (p. v-vi); the same Kurdish man of letters, he notes elsewhere, also erroneously transcribed the vowel /e/ in the middle of a word (p. VIII). By thus taking Arabic orthography as a normative standard, and by treating any deviations or differences in the writing of Kurdish (which knows no emphatic consonants) as errors on the mullah's part, Justi reduces Bayazîdi's role to that of an anonymous and ignorant native informant.

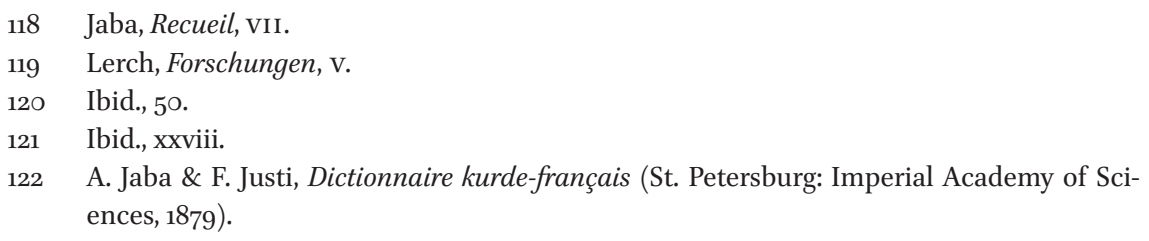


The results of this condescending attitude to native scholarship - or at least to the quality of Bayazîlî's writings - can clearly be seen in the writings of later Russian Kurdologists. Thus, Vladimir Minorsky's entry on the Kurds in the first edition of the Encyclopaedia of Islam clearly relies on materials written by or supplied by Bayazîdî - in particular, his overview of Kurdish poets - but nowhere refers to him by name, only mentioning an anonymous "informant" (Gewährsmann) of Jaba's in passing. ${ }^{123}$ Likewise, in his monograph Les kurdes, Basil Nikitine nowhere mentions Bayazîdî, even though he was familiar with the books written by the latter and published under Jaba's name. He speaks only generically of a "group of Kurdish scholars" allegedly helping Jaba in compiling a Kurdish chrestomathy. ${ }^{124}$ In short, imperial and post-imperial Russian Kurdological scholarship appears to have consistently if not systematically downplayed not just the importance but even the reliability of Bayazîdî's writings, and has even attempted to erase his name from Kurdological memory. And one suspects that his is not an isolated case. Clearly, the story of how early modern non-Western vernacular learning has been marginalized by European orientalism remains to be written.

\section{Conclusion}

The above should make clear that Mullah Mahmûdê Bayazîdî is a figure of paramount importance both for the political and the intellectual history of nineteenth-century Kurdistan. In particular, his role as an intermediary between the reforming Ottoman Empire and three of the most powerful Kurdish rulers of his time is worth exploring. Further research in British, Russian, and Ottoman archives may yield more details on developments in nineteenth-century Northern Kurdistan and on Bayazîlî's role in them.

Bayazîlî's writings are at least as interesting as his political actions. Apart from their inherent interest as the oldest sources on Kurdish literature and customs, and as the oldest samples of Kurdish prose, they merit attention for their content and conceptualizations. We know little or nothing, however, about which works served as sources or models for these writings, apart from such obvious texts as the Sherefname and Mem û Zîn, nor is there any evidence

123 V. Minorsky, “Kurden”, in Enzyklopaedie des Islam Bd. 2 (Leiden: Brill, 1927), 1212-37, esp. 1234-35.

124 Nikitine, Kurdes, 294. For an initial exploration of the importance of Bayazîdî's writings for Kurdish studies, see Jan Dost, "Bayezîlî û kurdolojî: Geşbûna pexşana kurdî di hembêza kurdolojiyê de”, in Kurdolojî: Gotarên Konferansa Kurdolojiyê , ed. by Ibrahim Aydogan (Hakkari: Hakkari Üniversitesi Yayinevi, 2012), 197-208. 
that he was familiar with either French, Russian, or Armenian ethnographies. Rather, it seems likely that Jaba would ask Bayazîdî to write about a specific topic, and that the latter would duly comply by writing a short text like those supplied in $C R H$, or a paragraph of a longer text like the $A R E$. Thus, the topics Bayazîdî discusses are generally those a philologically trained, and diplomatically active, modern European orientalist would be interested in, but the language in which these texts are written is still very much that of the premodern or early modern Islamic traditions of learning and letters.

Yet, his is not simply a "premodern" or a "traditional" outlook, given Bayazîdî's awareness that the vernacularization of Kurdish learning, which he dates to around the year $1000 \mathrm{AH}$, marks a major rupture in Kurdish cultural history. Likewise, romantic-nationalist categories of literature and fiction are absent from his writings, as are modern concepts of religion, culture, and tradition. Significantly, for the latter two, he consistently employs pejorative terms, like urf, 'adet and jâhiliyya. One can therefore hardly speak of a category of the native, in the sense of a timeless national individual endowed with pagan traditions, in particular a vernacular language and a national literature and folklore, as Nichanian has claimed for near-contemporary Armenian nationalism. Finally, the romantic-nationalistic vocabulary of national or political liberty is almost entirely absent from Bayazîdî's writings. He talks about freedom only in a context that involves gender rather than politics, and private rather than public or political matters - witness his comments in ARE that Kurdish women are as free (serbest) as French ones. Nowhere does he claim, however, that the Kurds as a people or Volk are not, but should be, free. In short, Bayazîdî's is no modernist narrative of historical progress, emancipation, or liberation. Likewise, the categories of romantic-nationalist philology are absent in his writings; thus, he presents a history not of Kurdish literature but of Kurdish poets, and he talks not of Kurdish culture but of Kurdish customs. His works do not involve any simple translation or passive reception of - supposedly dominant or hegemonic - Western philological orientalist categories.

But perhaps one should not look for what is absent from Bayazîlì's writings but instead explore what particular moment in Kurdish political and intellectual history they embody. They display an unmistakable sense of a distinct Kurdish identity that cannot be reduced to either hegemonic orientalist categories, derivative nationalism, or Russian imperialist influence. For this reason, Bayazîdî calls attention to, and indeed personifies, local forms of intellectual agency, as well as the importance of early modern vernacular learning, in the formation of ethnic identities, and subsequently national movements, in the reforming Ottoman Empire. 